ROZALIA KOSIŃSKA

Instytut Historii PAN, Warszawa

\title{
SEJMIKI POSELSKIE 1766 ROKU
}

\begin{abstract}
Abstrakt: Przedmiotem badań w niniejszym artykule są sejmiki 1766 r. Autor opisuje przygotowania do kampanii zarówno dworu, jak i opozycji, a następnie na podstawie instrukcji oraz korespondencji relacjonującej przebieg lokalnych zgromadzeń odpowiada na pytanie, czyim sukcesem się okazały sejmiki.
\end{abstract}

Słowa kluczowe: sejmiki, 1766 r., Stanisław August, Czartoryscy, dysydenci.
Abstract: The article focuses on the sessions of dietines (sejmiki, assemblies of the local nobility) convened in 1766 . The author presents the preparations for the campaign of both the court and the opposition, and then - on the basis of instructions and letters describing the course of local gatherings - answers the question of which side was victorious at the dietines.

Keywords: dietines, 1766, King Stanisław August, the Czartoryskis, dissidents.

Sejm 1766 r. to jeden z ważniejszych momentów w początkach panowania Stanisława Augusta. Konsekwencją niezaspokojenia wówczas żądań carycy Katarzyny II w tzw. sprawie dysydenckiej (czyli politycznego i religijnego równouprawnienia niekatolików) było zawiązanie pod rosyjskimi auspicjami najpierw konfederacji w Toruniu i Słucku w obronie praw protestantów oraz prawosławnych, a potem, 23 czerwca 1767 r., konfederacji w Radomiu. Aby przeforsować swoje żądania i utrwalić dominację, Rosja na obradującym pod węzłem konfederacji radomskiej i sterroryzowanym przez ambasadora Nikołaja Repnina [Nikolaj Repnin] sejmie 1767/1768 r. doprowadziła do uchwalenia równouprawnienia dysydentów oraz praw kardynalnych sankcjonujących wady polskiego ustroju, a następnie formalnie objęła je swoją gwarancją. Przebieg i postanowienia tego sejmu doprowadziły do wybuchu konfederacji barskiej. Zatem kampania sejmikowa 1766 r. była wstępem do dramatycznych wydarzeń, 
których kulminację stanowiły konfederacja barska i pierwszy rozbiór. Warto jej więc poświęcić osobne miejsce, tym bardziej że o sejmikach zwołanych na 25 sierpnia 1766 r. większość opracowań wspomina jedynie na marginesie głównych rozważań ${ }^{1}$.

W niniejszym tekście zamierzam opisać przygotowania króla i opozycji do sejmików, omówić ich przebieg, syntetycznie przeanalizować instrukcje poselskie ${ }^{2}$, a także wskazać obszary wpływów władcy i tzw.

${ }^{1}$ M.C. Łubieńska, Sprawa dysydencka 1764-1766, Warszawa 1911, s. 83-93; J. Łukowski, The szlachta and the Confederacy of Radom 1764-1767/1768. A Study of the Polish Nobility, Rzym 1977, s. 51-58, 113-133; Z. Zielińska, Polska w okowach „systemu pótnocnego” 1763-1766, Kraków 2012, s. 439-495. O sejmikach pruskich J. Dygdała, Życie polityczne Prus Królewskich u schyłku ich zwiazku z Rzeczapospolita w XVIII wieku. Tendencje unifikacyjne a partykularyzm, Warszawa 1984, s. 172-187.

${ }^{2} \mathrm{Z}$ ponad 60 instrukcji dotarłam do 34. O liczbie 69 sejmików, przy zastrzeżeniu, że w ciągu XVIII w. mogła ona ulec niewielkim zmianom, patrz W. Kriegseisen, Sejmiki Rzeczypospolitej szlacheckiej w XVII i XVIII wieku, Warszawa 1991, s. 28. O liczbie 61 instrukcji z 1764 r. patrz T. Szwaciński, Sejmiki poselskie przed konwokacja 1764 r., KH 113, 2006, 1, s. 19. W odniesieniu do Korony dysponuję 27 instrukcjami, gdy chodzi zaś o Wielkie Księstwo Litewskie to 7. Instrukcje z Korony: instrukcja krakowska, BC 839, k. 329-360; instrukcja wielkopolska, AGAD, Zbiór Popielów (dalej: ZP) 121, k. 71-74; instrukcja sandomierska, BC 8341, s. 733-772; instrukcja sieradzka, AGAD, Księgi grodzkie sieradzkie, relacje 137, s. 508-511; instrukcja wieluńska, AGAD, Księgi grodzkie wieluńskie, oblaty 20, s. 598-605; instrukcja łęczycka, AGAD, Księgi grodzkie łęczyckie, relacje i oblaty 241B, s. 146-151; instrukcja dobrzyńska, Lauda sejmików ziemi dobrzyńskiej, wyd. St. Kulczycki, Kraków 1887, s. 340-345; instrukcja kijowska, AGAD, ZP 121, k. 70; instrukcja ruska, AGZ, t. 23, s. 514-518; instrukcja halicka, AGZ, t. 24, s. 625-630; instrukcja wołyńska, AGAD, ZP 121, k. 79-85; instrukcja lubelska, BC 8326, s. 298-309; instrukcja bełska, BPAU-PANKr 314, s. 31-36; instrukcja płocka, AGAD, Księgi grodzkie płockie, oblaty 14, s. 98-101; instrukcja warszawska, BC 8349, s. 331-335; instrukcja wiska, BC 8351, s. 249-258; instrukcja wyszogrodzka, AGAD, Księgi grodzkie wyszogrodzkie, relacje 28, k. 432-433; instrukcja zakroczymska, AGAD, Księgi grodzkie zakroczymskie, relacje 67, k. 799-801; instrukcja ciechanowska, AGAD, ZP 121, k. 88-95; instrukcja łomżyńska, BC 8332, s. 374-383; instrukcja liwska, BC 8322, s. 526-531; instrukcja nurska, AGAD, Księgi grodzkie nurskie, relacje, oblaty 39, s. 87-89; instrukcja drohicka, AGAD, Archiwum Publiczne Potockich (dalej: APP) 313, k. 810-816; instrukcja bielska, Biblioteka Publiczna m.st. Warszawy, Silva 1764-1768 (dalej: Biblioteka), sygn. XVIII.3.2220, s. 505-508; instrukcja sochaczewska, BC 8347, s. 405-406; instrukcja bracławska, Biblioteka, sygn. XVIII.3.2219, s. 497-504; instrukcja czernihowska, Biblioteka, sygn. XVIII.3.2223, s. 515-521; Instrukcje z Wielkiego Księstwa Litewskiego: instrukcja wiłkomierska, AGAD, Archiwum Tyzenhauzów, E-494; instrukcja grodzieńska, Акты Виленской археографической комиссии (dalej: АWАК), Вильно 1874, t. 7, s. 350-359; instrukcja kowieńska, LVIA, Senieji Aktai 13710, k. 1345-1348; instrukcja starodubowska, AWAK, Wilno 1875, t. 8, s. 392-402; instrukcja brzeska, AWAK, Wilno 1870, t. 4, s. 583589; instrukcja pińska, Biblioteka, sygn. XVIII.3.2222, s. 515-518; instrukcja mścisławska, Biblioteka Litewskiej Akademii Nauk im. Wróblewskich w Wilnie (dalej: Biblioteka Wróblewskich), Fond 119-15. 
malkontentów, czyli opozycji antykrólewskiej. Niestety podstawa źródłowa nie jest równie obszerna dla wszystkich lokalnych zgromadzeń. Dla części z nich dysponuję tylko informacją, kto został wybrany posłem, przy innych mogę pokusić się o analizę przebiegu bądź pokazać, w jaki sposób powstawała instrukcja. Zatem stan bazy źródłowej determinuje zakres analizy.

Program króla na sejm 1766 r. obejmował rozwiązanie problemu dysydenckiego, ujednolicenie podatków czopowego i szelężnego z przeznaczeniem na aukcję wojska oraz utrzymanie utworzonej w $1765 \mathrm{r}$. Szkoły Rycerskiej3. Z kolei Rosja oczekiwała od Stanisława Augusta uchwalenia ustawodawstwa zwiększającego prawa protestantów i prawosławnych ${ }^{4}$, wytyczenia granicy polsko-rosyjskiej ${ }^{5}$ oraz włączenia Rzeczypospolitej do sojuszu północnego pod patronatem Petersburga ${ }^{6}$.

Król zdawał sobie sprawę z powagi sytuacji, a jednocześnie miał świadomość oporu szlachty wobec równouprawnienia innowierców, dlatego nie chciał forsować sprawy, która mogła uniemożliwić kontynuację reform. W kwietniu 1766 r., próbując bezskutecznie zmienić decyzję Katarzyny II w sprawie dysydentów, wysłał do niej list. W odpowiedzi Petersburg zagroził wojną, jeżeli nadchodzący sejm nie spełni żądań w sprawie innowierców ${ }^{7}$. Stanisław August, licząc, że zadowoli Rosję zwiększeniem jedynie swobód religijnych dla niekatolików, dążył do tego „żeby instrukcje poselskie to obostrzyły, żeby do senatu ani do poselskiej izby, ani do urzędów przypuszczeni nie byli dysydenci”, tym

3 Stanisław August do M. Brzostowskiego, 14 VIII 1766, BC 656, s. 241. W wyniku presji Prus wspartych przez Rosję, król musiał znieść wprowadzone w 1764 r. cło generalne i znaleźć zastępcze źródło dochodów dla państwa, Z. Zielińska, Rzeczpospolita między Prusami a Rosja w świetle polsko-pruskiego sporu o cło generalne, KH 115, 2008, 2, s. 5-52.

${ }^{4} \mathrm{Na}$ sejmie koronacyjnym $1764 \mathrm{r}$. Rosja bezskutecznie zażądała poszerzenia granic tolerancji religijnej względem innowierców oraz dopuszczenia ich do starostw niegrodowych. Winą za niespełnienie żądań obarczyła kanclerza wielkiego litewskiego Michała i wojewodę ruskiego Augusta Czartoryskich, kierujących Familią. Katarzyna II nie pogodziła się z porażką i w 1766 r. powiększyła zakres żądań o dostęp do funkcji sądowych, poselstw i wyższych urzędów w państwie dla szlachty niekatolików, M.C. Łubieńska, op. cit., s. 39-47; Z. Zielińska, Polska w okowach, passim; W. Kriegseisen, Dysydenci i dyzunici w Rzeczypospolitej epoki stanisławowskiej, w: Stanisław August i jego Rzeczpospolita. Dramat państwa, odrodzenie narodu, t. 2, red. A. Sołtys, Z. Zielińska, Warszawa 2013, s. 51-63; O stosunku Stolicy Apostolskiej do sprawy dysydenckiej patrz J. Łukowski, The Papacy, Poland, Russia and religious reform 1764-8, „Journal of Ecclesiastical History” 39, 1988, s. 66-94.

${ }^{5}$ Z. Zielińska, Polska w okowach, s. 22, 202, 213, 219-226, 238, 469-470.

${ }^{6}$ Ibidem, s. 198, 201, 280-281, 390, 470.

7 Ibidem, s. 456-457, 470 .

8 Stanisław August do M. Brzostowskiego, 14 VIII 1766, BC 656, s. 241. 
samym usiłował zabezpieczyć się przed żądaniami dotyczącymi praw politycznych. Król polecił swoim zaufanym ludziom w Wielkopolsce podjęcie starań o umieszczenie $\mathrm{w}$ instrukcjach punktu przyznającego innowiercom prawo swobody kultu w dobrach prywatnych oraz stałą wysokość iura stolae, tj. opłat za chrzty, śluby i pogrzeby, co chroniłoby ich przed nadużyciami ze strony kleru katolickiego. Umiarkowane propozycje królewskie nie napotkały na opór współpracowników ${ }^{9}$. Pierwotnie król zamierzał wnieść sprawę dysydencką bezpośrednio pod obrady sejmu. Ostatecznie uznał, iż będzie ona łatwiejsza do przeforsowania, „jeżeli kilku posłów będzie miało ją poruczoną w instrukcjach"10.

Jeśli zaś chodzi o wprowadzenie generalnego czopowego i szelężnego z przeznaczeniem na aukcję wojska, monarcha przygotowywał reformę bez rozgłosu, zamierzając osobiście wprowadzić ją pod obrady ${ }^{11}$. Instrukcje miały domagać się jedynie „[tego] same[go] czopowe[go] i szelężne[go] in genere ze wszystkich miast $\mathrm{i}$ wsi" ${ }^{12}$. Władca, znając uprzedzenia poddanych, za pierwszy etap reform wojskowych uznał urealnienie etatu ustalonego na sejmie $1717 \mathrm{r} .{ }^{13}$ Tym samym środki wyznaczone na 24 tys. porcji chciał przeznaczyć wyłącznie na żołd dla szeregowych, a na wynagrodzenie dla oficerów oraz podoficerów znaleźć oddzielny fundusz ${ }^{14}$.

Sprawę dysydencką, generalne czopowe i szelężne, a także aukcję wojska pominięto w uniwersale przedsejmowym z 16 lipca 1766 r. Kanclerz koronny Andrzej Zamoyski oraz wojewoda ruski August Czartoryski radzili, aby jego treść była enigmatyczna, uważając, że łatwiej będzie

9 Stanisław August do M. Czartoryskiego, 14 VII 1766, BC 659, s. 329-336.

10 „quand quelques nonces en avaient chargés par leurs instructions”, Stanisław August do M. Czartoryskiego, 14 VII 1766, BC 659, s. 329-336.

${ }^{11}$ Dotychczas w Koronie czopowe i szelężne szło głównie na doraźną pomoc oraz wynagrodzenie urzędników samorządowych. W Wielkim Księstwie Litewskim podatki służyły pokryciu długów zaciągniętych jeszcze przed sejmem 1717 r. na utrzymanie wojska, M. Nycz, Geneza reform skarbowych Sejmu Niemego. Studium z dziejów skarbowo-wojskowych z lat 1697-1717, Poznań 1938, s. 76-83.

12 O kształcie reformy skarbowej dowiadujemy się z odręcznych uwag króla poczynionych na liście cześnika Tadeusza Dzieduszyckiego do Jacka Ogrodzkiego, 2 VIII 1766, BC 660, s. 176.

${ }^{13}$ Uprzedzenia szlachty wynikały z doświadczeń z okresu wojny północnej, E. Rostworowski, Sprawa aukcji wojska na tle sytuacji politycznej przed sejmem czteroletnim, Warszawa 1957, s. 27-30.

${ }^{14}$ M. Czartoryski do Stanisława Augusta, 9 VII 1766, BC 659, s. 317-321; Stanisław August do M. Czartoryskiego, 14 VII 1766, BC 659, s. 329-336; Protokół konferencji króla z ministrami, BC 653 (dalej: Protokół), 16 VIII, 2 X 1766, s. 421, 507-508. Sejm 1717 r., redukując armię, nie wyznaczył osobnych porcji dla kadry dowódczej, dlatego realnie zmniejszono liczbę żołnierzy do 14-16 tys., choć etat został ustalony na poziomie 24 tys., E. Rostworowski, Sprawa aukcji wojska, s. 27. 
przekonać posłów na sejmie, niż szlachtę na sejmikach ${ }^{15}$. Ponadto za radą Czartoryskiego, dla zabezpieczenia się przed protestami przeciwko przedłużeniu obrad, z uniwersału usunięto słowo „sześcioniedzielny”16. Kanclerz wielki litewski Michał Czartoryski zaś (już po zakończeniu prac nad uniwersałem) zalecał ujawnienie programu królewskiego, ostrzegając, że posłowie mogą odmówić uchwalenia projektu, który został pominięty w uniwersale ${ }^{17}$. Nie zgodził się też napisać do przyjaciół z prośbą o poparcie postulatu utrzymania Korpusu Kadetów ${ }^{18}$. 25 czerwca pokazano tekst uniwersału Repninowi, ów przesłał go szefowi rosyjskiego kolegium spraw zagranicznych Nikicie Paninowi [Nikita Panin]. Z rozpowszechnieniem dokumentu wstrzymano się do czasu nadejścia aprobaty z Petersburga, tj. do 14 lipca ${ }^{19}$. Ostatecznie przedmiot obrad przedstawiono oględnie jako uzupełnienie ustawodawstwa dotyczącego komisji wojskowych i skarbowych, zwiększenie płacy wojska oraz określenie środków na ten cel, a także uporządkowanie oraz objaśnienie prawa ${ }^{20}$.

W instrukcji skierowanej na sejmiki władca szerzej przedstawił swój program. Priorytetem było zabezpieczenie dorobku dwóch ostatnich sejmów doby elekcji. Król zalecał uściślenie ustawodawstwa dotyczącego Komisji Skarbowej i Wojskowej, następnie podziękowania dla siebie za przeprowadzenie reformy monetarnej oraz usunięcie z kraju zagranicznych monet. W związku z delimitacją, chcąc zabezpieczyć się przed rosyjskimi roszczeniami, proponował, aby posłowie domagali się zagwarantowania nienaruszalności granic. Chciał też, żeby mieli poruczone polepszenie sytuacji finansowej wojska bez odwoływania się do sejmików. Stanisław August explicite wspomniał o aukcji, dodając, że nie będzie nakładać żadnych nowych podatków. Jedynie, wbrew obietnicy z 1764 r., planował pozostawić podymne, choć w formie zreformowanej ${ }^{21}$. Świadom niewielkich dochodów państwa, nie mógł rezygnować z żadnych wpływów do skarbu. Zalecił, aby czopowe i szelężne w Koronie

15 Protokół, 6 VI 1766, s. 299; Stanisław August do M. Czartoryskiego, 3 VII 1766, BC 659, s. 313-315.

16 Protokół, 21 VI 1766, s. 325.

${ }^{17}$ List kanclerza z kontrprojektem został wysłany 1 lipca, a odczytany na naradzie z ministerium 3 lipca, czyli w dniu, w którym ekspedycja sejmikowa została oddana do drukarni, M. Czartoryski do Stanisława Augusta, 1 VII 1766, BC 659, s. 307-311; Protokół, 3 VII 1766, s. 345.

${ }^{18}$ M. Czartoryski do Stanisława Augusta, 9 VII 1766, BC 659, s. 317-321.

19 Z. Zielińska, Polska w okowach, s. 472.

${ }^{20}$ Uniwersał królewski, AGAD, Zbiór Dokumentów Papierowych, 0124; J. Michalski, Zagadnienie reformy sądownictwa i prawa sądowego w poczatkach panowania Stanisława Augusta, CPH 52, 2000, 1-2, s. 95-96.

${ }^{21}$ VL 7, s. 146. 
i na Litwie zostały ujednolicone. Proponował kodyfikację leges iudiciarias, która obejmowałaby prawo cywilne, karne, procesowe oraz przepisy o ustroju sądów, a następnie prawo prywatne ${ }^{22}$. Kodyfikacji miała dokonać komisja, wyniki prac przedstawiłaby na sejmie w 1768 r. Przy okazji narodziła się myśl stworzenia Kodeksu Stanisława Augusta, jednak jeszcze przed obradami sejmu została zaniechana ${ }^{23}$. W instrukcji królewskiej pojawiła się - pominięta w uniwersale - prośba o fundusze na Szkołę Rycerską, a także poruszono problem Kurlandii, która formalnie pozostawała lennem Rzeczypospolitej. Król na życzenie Repnina chciał, aby sejm potwierdził prawa rosyjskiego protegowanego, Ernsta Johanna Birona, do godności książęcej i zatwierdził jego decyzje podjęte po powrocie $\mathrm{z}$ wygnania ${ }^{24}$. Sprawa ta nie znalazła się w uniwersale ze względu na emocje, które budził w Rzeczypospolitej spór Birona ze szlachtą kurlandzką ${ }^{25}$. W kontekście przygotowań do sejmu należy osobno wspomnieć o Czartoryskich. Po roku 1764 popadli oni w Petersburgu w niełaskę. Jednak Rosja przed sejmem 1766 r. doszła do wniosku, że bez Czartoryskich nie przeforsuje swoich żądań. Familia bezskutecznie starała się zmienić decyzję Katarzyny II w sprawie dysydentów lub przynajmniej zabezpieczyć się przed oskarżeniami o niepowodzenie akcji ${ }^{26}$. Wyjazd Michała Czartoryskiego z Warszawy do Wołczyna 30 maja 1766 r. wiązał się z przygotowaniem do sejmików litewskich ${ }^{27}$. Kanclerz popierał starania króla o uwzględnienie w traktacie sojuszniczym z Rosją postanowień z 1704 r., które przyznawały Polsce Inflanty. Wiedział jednak, że Katarzyna II nie zrezygnuje $\mathrm{z}$ tego terytorium, zatem w ramach rekompensaty oraz w związku z planowanym włączeniem Rzeczypospolitej do sojuszu liczył na uzyskanie zgody na aukcję wojska i na sfinansowanie jej przez Rosję ${ }^{28}$. Czartoryski szeroko nakreślił zakres polskich żądań,

${ }^{22}$ E. Borkowska-Bagieńska, „Zbiór praw sądowych” Andrzeja Zamoyskiego, Poznań 1986, s. 72.

${ }^{23}$ Jeszcze 11 września projekt był aktualny, 2 października przestał być brany pod uwagę, Protokół, 11 IX, 2 X 1766, s. 464, 509. O planach z 1766 r. brak mowy w opracowaniach poświęconych kodeksowi: Ł. Kurdybacha, Dzieje Kodeksu Andrzeja Zamoyskiego, Kraków 1951; E. Borkowska-Bagieńska, op. cit.

${ }^{24}$ Punkty do instrukcji posłom na sejmiki 1766 r., AGAD, Zbiór Branickich z Suchej, 134/158 (dalej: Zbiór), s. 621-623; Z. Zielińska, Polska w okowach, s. 471-472.

25 Б. Носов, Установление российского господства в Речи Посполитой. 1756-1768 г2., Москва 2004, s. 72-80, 157, 216-224.

${ }^{26}$ Z. Zielińska, Polska w okowach, s. 449, 457-458, 469-470, 486-488.

27 J. Michalski, Problematyka aliansu polsko-rosyjskiego, w: idem, Studia historyczne z XVIII i XIX wieku, t. 1: Polityka i społeczeństwo, Warszawa 2007, s. 335-362; Z. Zielińska, Polska w okowach, s. 463.

${ }^{28}$ M. Czartoryski do Stanisława Augusta, 6 VI 1766, BC 659, s. 291-293. 
aby w czasie pertraktacji zrezygnować z pomocy pieniężnej i uzyskać przynajmniej zgodę na aukcję. Ponadto król wraz z wojewodą ruskim i kanclerzem wielkim litewskim wielokrotnie podkreślali konieczność wycofania wojsk rosyjskich z Rzeczypospolitej, ponieważ, żywiąc się na koszt poddanych, rujnowały one gospodarkę, a także - co miało dodatkowo przekonać Petersburg - utrudniały realizację postulatów w sprawie dysydenckiej ${ }^{29}$. Kanclerz litewski ostrzegał jednocześnie siostrzeńca, że zwiększenie praw innowierców będzie oznaczało konflikt z poddanymi, a to z kolei zagrozi reformom. Nie chcąc zaś występować jako promotor sprawy, która mogłaby zaszkodzić jego wizerunkowi, odmówił pomocy w agitacji na rzecz niekatolików ${ }^{30}$. Niechętna forsowaniu sprawy dysydenckiej na sejmikach postawa Czartoryskich nie była tajemnicą ${ }^{31}$. Do tej pory o nieprzejednanym stanowisku szlachty względem innowierców świadczyli król i jego wujowie, teraz miał przemówić stan rycerski, co stanowiłoby dodatkową formę nacisku na Rosję.

Czartoryscy, choć popierali niektóre elementy polityki króla, podejmowali także decyzje za plecami lub wbrew woli monarchy. Jego rozgoryczenie wzbudziła odmowa ze strony kanclerza wielkiego litewskiego przyznania mandatu z Brześcia pułkownikowi husarskiemu Franciszkowi Ksaweremu Sapiesze ${ }^{32}$. Stanisław August przesunął protegowanego, zgodnie z sugestią wuja, na sejmik czernihowski. Ostatecznie jednak lista posłów z Litwy zaproponowana przez wujów monarchy wzbudziła w królu nadzieję na pomyślny przebieg sejmu ${ }^{33}$. Także odnośnie do sejmików koronnych Stanisław August spotkał się z brakiem pełnej współpracy ze strony Czartoryskich. Wojewoda ruski, cieszący się liczną klientelą i szerokimi wpływami sięgającymi także Mazowsza, odmówił wyjawienia planów obsady mandatów z różańskiego i ciechanowskiego. Można skonstatować, że liderzy Familii, chcąc utrzymywać kontrolę nad Stanisławem Augustem, starali się uniemożliwić władcy budowę własnego stronnictwa ${ }^{34}$. Mimo ich postawy król pragnął załagodzić sytuację, aby nie eskalować napięcia z wujami ${ }^{35}$.

${ }^{29}$ M. Czartoryski do Stanisława Augusta, 6 VI, 16 VI 1766, BC 659, s. 291-293, 297-301.

30 M. Czartoryski do Stanisława Augusta, 22 VII 1766, BC 659, s. 337-343.

${ }^{31}$ Bp J.D. Łopaciński do M. Łopacińskiego, 19 VII, 15 IX, 22 IX 1766, LVIA, F 1135, op. 8, nr 4 (dalej: LVIA), k. 159-160, 161-162.

${ }^{32}$ M. Czartoryski do Stanisława Augusta, 9 VII 1766, BC 659, s. 317-321.

33 Stanisław August do M. Czartoryskiego, 14 VII 1766, BC 659, s. 329-335.

34 S. Kościałkowski, Antoni Tyzenhauz. Podskarbi nadworny litewski, t. 1, Londyn 1970, s. 77-78.

35 Protokół, 25 VII, 13 VIII 1766, s. 383-384, 415. 
Rosja, wspierając oficjalnie władcę oraz Familię, jednocześnie starała się przyciągnąć opozycję. Choć jeszcze w sierpniu 1765 r. Repnin nie był zainteresowany taką współpracą, to wobec zbliżającego się sejmu zmienił zdanie. 20 stycznia 1766 r. przekazał Paninowi ofertę złożoną przez podskarbiego koronnego Teodora Wessla w imieniu własnym oraz wojewody kijowskiego Franciszka Salezego Potockiego, biskupa krakowskiego Kajetana Sołtyka, hetmana polnego koronnego Wacława Rzewuskiego i marszałka nadwornego koronnego Jerzego Mniszcha. Malkontenci za warunek współpracy uznali wystąpienie Rosji przeciwko Familii, udzielenie poparcia opozycji i rozwiązanie funkcjonującej od $1764 \mathrm{r}$. konfederacji ${ }^{36}$. Przed 27 marca 1766 r. Wessel usłyszał od Repnina, że dopiero niewywiązanie się króla i Czartoryskich z powierzonych im zadań będzie mogło spowodować ich odsunięcie ${ }^{37}$. Nadesłana z Petersburga odpowiedź potwierdziła słowa Repnina, któremu Panin zalecił jednak poinformować najbardziej zaufanych malkontentów, że w zamian za poparcie w sprawie dysydenckiej mogą liczyć na protekcję Rosji kosztem Familii ${ }^{38}$. Ostudziło to zapał opozycji, która nie zamierzała propagować wśród szlachty programu prodysydenckiego. Dlatego też negocjacje szły opornie. Wessel z zaproszenia do Warszawy wymówił się chorobą, a Mniszech w sprawie dysydenckiej domagał się szczegółów, których Repnin nie mógł mu wyjawić. Ambasador miał jednak wspomnieć o planie stworzenia partii zależnej wyłącznie od Rosji ${ }^{39}$. Opozycja nie ufała Rosjanom, dającym mgliste nadzieje na przyszłość w zamian za poparcie dla dysydentów. Zbyt wczesne przyjęcie takiej postawy malkontenci mogliby przypłacić spadkiem poparcia wśród szlachty, nic w zamian nie otrzymując. Doszli zatem do wniosku, że jeżeli król poniesie porażkę na sejmie, to wtedy Rosja powinna ich poprzeć. Michał Wielhorski postanowił przyjąć postawę wyczekującą ${ }^{40}$, której sens wyjaśnił w liście napisanym już w trakcie sejmu. Wyraził w nim nadzieję, że Repnin nie dojdzie z wojewodą ruskim i królem do konsensu, ponieważ ,jak tylko to się stanie, czego chce Rosja, znowu się z królem pokumają, a my tak zostaniemy, jak jesteśmy. Król się nakłania, to tem gorzej"41.

${ }^{36}$ M.C. Łubieńska, op. cit., s. 84; Z. Zielińska, Polska w okowach, s. 440.

37 T. Wessel do J. Mniszcha, 27 III 1766, BC 3861, s. 227-230.

${ }^{38}$ M.C. Łubieńska, op. cit., s. 84-85; J.T. Łukowski, The szlachta, s. 50; Z. Zielińska, Polska w okowach, s. 440-441.

39 Z. Zielińska, Polska w okowach, s. 466.

40 M. Wielhorski do J. Mniszcha, 13 VII 1766, BC 3861, s. 313-316.

${ }^{41}$ M. Wielhorski do J. Mniszcha, 20 XI 1766, BC 3861, s. 495-496; K. Rudnicki, Biskup Kajetan Sołtyk 1715-1788, Warszawa 1906, s. 135. Zdaniem Jerzego J. Głowackiego powodem oddalenia perspektywy współpracy było postępowanie ambasadora wobec Sołtyka 
Mimo starań Repnina opozycja podjęła agitację antydysydencką. Rolę spiritus movens grał biskup Sołtyk. W połowie marca dwór podjął bezskuteczną próbę przejednania go w sprawie innowierców ${ }^{42}$. Nie powstrzymało to hierarchy przed rozesłaniem na początku lipca listu duszpasterskiego, w którym zachęcał do oporu wobec żądań innowierców, a w razie ustępstw straszył rozlewem krwi ${ }^{43}$. Współpracownikiem Sołtyka był Mniszech, który przed sejmikami rozpoczął zabiegi o laskę wielką koronną ${ }^{44}$. Do Warszawy przybył w czerwcu i spotkał się z Repninem, ów zaś wyraźnie zabiegał o jego względy ${ }^{45}$. Także król starał się zneutralizować Mniszcha za pośrednictwem wojewody kaliskiego Ignacego Twardowskiego, grożąc utratą szans na marszałkostwo ${ }^{46}$. Po 12 lipca odbyło się poufne spotkanie Sołtyka i Mniszcha w Piotrawinie ${ }^{47}$. Korespondencja dotycząca tego zjazdu była datowana z Opola, gdzie biskup prawdopodobnie składał wizytę wojewodzie lubelskiemu Antoniemu Lubomirskiemu ${ }^{48}$, z którym opracowywał plan działania na zbliżające się sejmiki i sejm.

Poirytowany Repnin za pośrednictwem pijara ks. Ćwierzniewskiego ostrzegł Sołtyka, że jeżeli nie porzuci akcji antydysydenckiej, to dobra jego i jego krewnych zostaną zasekwestrowane, współpracując zaś będzie mógł liczyć na łaski Katarzyny II. Rozjuszony biskup wystosował do króla list, którym próbował zastawić na monarchę pułapkę ${ }^{49}$. Gdyby ten w odpowiedzi bronił Repnina, zdyskredytowałby się w oczach poddanych, z kolei ujęcie się za biskupem sprowokowałoby niechęć Katarzyny II ${ }^{50}$.

i „obawa o szkodę państwa i własnego interesu”. Autor nie wyjaśnił, co owa szkoda miała oznaczać, J.J. Głowacki, Gastronomia polityczna kuchmistrza litewskiego. Michał Wielhorski (ok. 1731-1814) - życie i myśl ustrojowa, Warszawa 2014, s. 113.

${ }^{42}$ Bp K. Sołtyk do bp. E. Wołłowicza, 15 III 1766, Biblioteka, sygn. XVIII.3.2164, s. 410-412; bp K. Sołtyk do Stanisława Augusta, 6 V 1766, AGAD, Metryka Litewska IX 107 (dalej: M. Lit.), s. 127-129.

${ }^{43}$ List pasterski bp. Sołtyka z 8 VII 1766, AGAD, ZP 121, k. 115.

44 Stanisław August do M. Czartoryskiego, 22 VI 1766, BC 659, s. 303-305.

45 J. Michalski, Warszawa, czyli o antyspołecznych nastrojach $w$ czasach Stanisława Augusta, w: idem, Studia historyczne z XVIII i XIX wieku, t. 2: Ideologia, nauka, historiografia, Warszawa 2007, s. 38-42; M. Wielhorski do J. Mniszcha, 13 VII 1766, BC 3861, s. 313-316.

${ }^{46}$ I. Twardowski do J. Mniszcha, 21 VIII 1766, BC 3861, s. 343-346.

${ }^{47}$ Bp K. Sołtyk do J. Mniszcha, 24 VI, 29 VI 1766, BC 3861, s. 305-306, 309-311. Fragmenty dotyczące działań Sołtyka przed sejmikami oraz przebiegu obrad w Proszowicach napisałam w oparciu o swój artykuł, Wpływ opozycji na przebieg i wyniki sejmiku poselskiego w Proszowicach $w 1766$ roku, w: Zmierzch i świt. Stanisław August i Rzeczpospolita 1764-1795, red. A. Antoniewicz, R. Kosińska, P. Skowroński, Warszawa 2015, s. 65-82.

${ }^{48}$ Bp K. Sołtyk do J. Mniszcha, 3 III, 8 III 1766, BC 3861, s. 139-143, 159-162.

49 Protokół, 3 VIII, 4 VIII, 5 VIII 1766, s. 397-401; K. Rudnicki, op. cit., s. 112.

${ }^{50}$ K. Rudnicki, op. cit., s. 110-111; M.C. Łubieńska, op. cit., s. 89; Z. Zielińska, Polska wokowach, s. 481-83. 
Równolegle z listem do Stanisława Augusta Sołtyk napisał w bojowym duchu dwa kolejne. W zaadresowanym do Wessla (pośrednio do Repnina) zaznaczył, że nie przestraszył się pogróżek, w drugim - do Mniszcha - wyraził gotowość do oddania życia za wiarę ${ }^{51}$. Król w zaaprobowanej przez Repnina odpowiedzi tłumaczył, że ks. Ćwierzniewski musiał wypaczyć sens wypowiedzi ambasadora. Monarcha, chcąc przeciwdziałać agitacji Sołtyka, zamierzał wręczyć swoją odpowiedź Stanisławowi Lubomirskiemu, aby ten „mógł różnym w poufałości pokazać, ale nie dając kopii" ${ }^{2}$. Czy tak się stało, nie wiemy.

Nie czekając na odpowiedź władcy, Sołtyk 5 sierpnia napisał do faworyta Katarzyny II, Grigorija Orłowa. Liczył bowiem, że Repnin działał wbrew woli carycy i spodziewał się jego dymisji. Pięć dni później biskup rozesłał kolejne listy, tym razem do monarchów katolickich z prośbą o pomoc w odparciu roszczeń dysydentów, wspieranych przez dwory protestanckie ${ }^{53}$. Nie ustając $w$ agitacji, przesłał Mniszchowi obiecane kopie listów na sejmiki i prosił o pomoc $\mathrm{w}$ ich propagowaniu ${ }^{54}$. Ponadto Sołtyk rozesłał na sejmiki list datowany na 13 sierpnia, a będący przy-

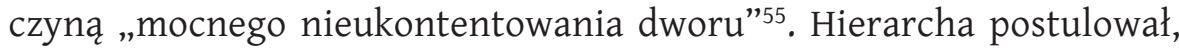
aby sejm potwierdził konstytucję z 1764 r., sankcjonującą wykluczenie innowierców z urzędów, tytułów, królewszczyzn oraz potwierdzającą zakaz sprawowania przez nich publicznego kultu. W innym wypadku straszył wojną domową, niechybną w obliczu „różności religijnej” oraz dominacją dysydentów w senacie, trybunałach, izbie poselskiej oraz na wysokich urzędach. Wstawiał się także za katolikami w Kurlandii, domagając się dla nich swobody kultu. W piśmie nie ograniczył się wyłącznie do haseł antydysydenckich, ale agitował na rzecz obalenia reform $1764 \mathrm{r}$. i rozwiązania konfederacji Czartoryskich, jako warunku ocalenia złotej wolności. W celu usprawnienia porządku sejmowania Sołtyk proponował, żeby za pomocą losowania decydować, które sprawy rozpatrywać na danym sejmie, które odłożyć do następnego, a które odrzucić. Przyjęte pod obrady miały podlegać głosowaniu większością. Biskup żądał, aby podatek ultimae consumentiae nie został zwiększony, a czopowe i szelężne pozostały w gestii województw. Wprost wypominał dworowi rozrzutność przy remoncie Zamku warszawskiego oraz trwonienie dochodów

${ }^{51}$ Bp K. Sołtyk do T. Wessla, 1 VIII 1766, BPAU-PANKr 314 (kopia); bp K. Sołtyk do J. Mniszcha, 2 VIII 1766, BC 3861, s. 323-324.

52 Protokół, 17 VIII 1766, s. 423-424.

${ }^{53}$ List bp. K. Sołtyka do G. Orłowa, AGAD, ZP 121, k. 119-120; List bp. Sołtyka do katolickich władców, AGAD, ZP 121, k. 120; K. Rudnicki, op. cit., s. 114.

${ }^{54}$ Bp K. Soltyk do J. Mniszcha, 9 VIII 1766, BC 3861, s. 335-337.

55 I. Twardowski do J. Mniszcha, 20 VIII 1766, BC 3861, s. 347-348. 
z pogłównego żydowskiego i kwarty. Postulował pozostawienie starej monety. Atakował komisje skarbowe i wojskowe ${ }^{56}$. Ostrzegał przed sojuszami, w domyśle z Rosją. Zalecał upomnienie się o raport z prac komisji granicznej oraz o opuszczenie Rzeczypospolitej przez wojsko rosyjskie ${ }^{57}$. Sołtyk, tłumacząc się z listu przed dworem, załączył rozkolportowane po kraju listy księży Michała Moszyńskiego i Jazdowskiego, opisujące ciężką sytuację katolików w Kurlandii ${ }^{58}$. Rozsierdzony aktywnością hierarchy Repnin chciał wysłać do dóbr biskupich wojsko. Powstrzymali go król i August Czartoryski, wiedząc, że „spadłoby to na króla, a z sejmu siła by się rozjechała" 59 .

Sołtyka wspierali biskupi łucki Erazm Wołłowicz, podolski Adam Krasiński, kujawski Antoni Kazimierz Ostrowski, chełmiński Andrzej Baier, chełmski Feliks Turski, żmudzki Jan Dominik Łopaciński oraz kijowski Józef Załuski. Pierwsi trzej postawę opozycyjną wyrazili w listach pasterskich, czwórka pozostałych w odpowiedziach na deliberatoria ${ }^{60}$. Ostrowski razem z Sołtykiem mobilizowali duchowieństwo. W liście do biskupów zachęcali do solidarnego wystąpienia na sejmikach i sejmie oraz proponowali naradę nie tylko w sprawie dysydenckiej, ale także (co znamienne) w obronie wolności. Przedstawili propozycje do instrukcji poselskiej, które pokrywały się z treścią niżej omówionego listu biskupa krakowskiego na sejmik w Proszowicach ${ }^{61}$. Równie silnie emocje, co list biskupa krakowskiego, wzbudził na dworze list na sejmiki biskupa podolskiego Krasińskiego. Autora zamierzano postawić nawet przed sądem sejmowym tudzież konfederackim ${ }^{62}$. Pismo, utrzymane w histerycznym tonie, zawierało postulaty identyczne z tymi autorstwa Sołtyka, mimo że Repnin próbował wcześniej przejednać Krasińskiego w sprawie dysydenckiej ${ }^{63}$.

${ }^{56}$ W komisjach opozycja widziała zamach na „złotą wolność”, J. Michalski, Warszawa, s. 38-42.

${ }^{57}$ List pasterski bp. Sołtyka, AGAD, ZP 121, k. 43-47.

58 Bp K. Sołtyk do Stanisława Augusta, [b.d.], AGAD, APP 313, t. 2, s. 281-282.

59 Protokół, 17 VIII 1766, s. 423-424.

${ }^{60}$ List pasterski bp. Wołłowicza, AGAD, ZP 121, k. 117-118; List pasterski bp. Krasińskiego, BPAU-PANKr 314, s. 73-75; List pasterski bp. Ostrowskiego, AGAD, ZP 121, k. 116; bp A. Baier do Stanisława Augusta, 2 VIII 1766, BC 657; bp F. Turski do Stanisława Augusta, 21 V 1766, M. Lit., s. 146; bp J.D. Łopaciński do Stanisława Augusta, 22 VI 1766, M. Lit., s. 197-200, bp. J. Załuski do Stanisława Augusta, 2 VI 1766, M. Lit., s. 189-192.

${ }^{61}$ Bp K. Sołtyk do bp. E. Wołłowicza, VIII, 1766, Biblioteka, XVIII-3.2169, s. 418419. O otrzymanych pismach informował brata biskup żmudzki, bp J.D. Łopaciński do M. Łopacińskiego, 6 X, 10 X 1766, LVIA, k. 135-136, 137.

${ }^{62}$ Protokół, 8 IX 1766, s. 457.

${ }^{63}$ Z. Zielińska, Polska w okowach, s. 483. 
Osobno warto przyjrzeć się postawie prymasa Władysława Łubieńskiego. Pierwotna wersja jego listu pasterskiego zyskała aprobatę króla, ale nie Repnina ${ }^{64}$. Ambasador wykreślił fragment o „szczęśliwości kraju pod jedną wiarą, jednym duchem kościoła św. rzymskiego katolickiego", stwierdzenie, że król „nie zażywa obcych rad” oraz słowa o konieczności „ubezpieczenia sił przeciwko obcym najazdom”65. List rozkolportowano zanim Repnin naniósł poprawki, dlatego król prosił Michała Czartoryskiego, żeby odesłał mu nieocenzurowane egzemplarze. Kanclerz nie odzyskał trzech z nich i pierwotna wersja pozostała w obiegu ${ }^{66}$. W poprawionym liście prymas chwalił króla za oparcie rządów na gruncie prawa, korzystanie z rad senatu, ufundowanie Szkoły Rycerskiej, popierał reformę monetarną i przeznaczenie czopowego i szelężnego na żołd. Drażliwą kwestię konfederacji generalnej pozostawił do decyzji województw ${ }^{67}$. Ośmielony wystąpieniami innych hierarchów prymas do kwestii innowierców nawiązał w liście z 20 sierpnia, w którym zachęcał szlachtę do obrony praw wiary katolickiej ${ }^{68}$.

Odpowiedzi senatorów świeckich na deliberatoria współbrzmiały z głosami biskupów ${ }^{69}$. Enigmatyczny list Franciszka Salezego Potockiego oraz prośba Wacława Rzewuskiego o przywrócenie do łask zięcia banity Karola Stanisława Radziwiłła sygnalizowały sympatię dla opozycjonistów.

${ }^{64}$ Stanisław August do M. Czartoryskiego, 22 VII 1766, BC 659, s. 336.

${ }^{65}$ List pasterski prymasa z 24 lipca z uwagami Repnina, BC 659, s. 345-347.

${ }_{66}$ M. Czartoryski do Stanisława Augusta, 25 VII, 2 VIII 1766, BC 659, s. 349, 351; List prymasa na sejmiki bez uwag Repnina, AGAD, Zbiór, s. 616-618.

${ }^{67}$ List pasterski prymasa, BO 1405, s. 95-98.

${ }^{68}$ List pasterski prymasa z 20 sierpnia, AGAD, ZP 121, k. 114.

${ }^{69}$ Odpowiedzi, które udało mi się odnaleźć: W. Rzewuski do Stanisława Augusta, 21 VIII 1766, BC 795; F.S. Potocki do Stanisława Augusta, 24 V 1766, M. Lit., s. 154-155; M. Czapski do Stanisława Augusta, 8 V 1766, M. Lit., s. 130-132; J.K. Branicki do Stanisława Augusta, 28 IV 1766, M. Lit., s. 112-113; M. Massalski do Stanisława Augusta, 27 V 1766, M. Lit., s. 163-165; A. Dąmbski do Stanisława Augusta, [b.d.], M. Lit., s. 194-196; P. Dąmbski do Stanisława Augusta, 3 V 1766, M. Lit., s. 124-126; L.B. Podhorodeński do Stanisława Augusta, 22 V 1766, M. Lit., s. 150-153; T. Sołtyk do Stanisława Augusta, 10 V 1766, AGAD, APP 313, t. 2, s. 194-195; R. Gurowski do Stanisława Augusta, 24 V 1766, M. Lit., s. 156-159; K. Granowski do Stanisława Augusta, 29 V 1766, M. Lit., s. 168-173; T. Sołtyk do Stanisława Augusta, 10 V 1766 AGAD, APP 313, t. 2, s. 194-195; R.M. Jabłonowski do Stanisława Augusta, 28 V 1766, M. Lit., s. 174-177; J.H. Skarbek do Stanisława Augusta, M. Lit., 28 IV 1766, s. 178-181; T. Lipski do Stanisława Augusta, 30 V 1766, M. Lit., s. 107-108; J.S. Jakliński do Stanisława Augusta, 3 V 1766, M. Lit., s. 121-122; J. Hylzen do Stanisława Augusta, 9 V 1766, M. Lit., s. 133-137; T. Ogiński do Stanisława Augusta, 10 V 1766, M. Lit., s. 138-139; I. Ogiński do Stanisława Augusta, 1 VI 1766, M. Lit., s. 186-188; M. Stadnicki do Stanisława Augusta, 12 VII 1766, M. Lit., s. 201-204; opracowanie: J. Michalski, Jabłonowski Roch Michał, PSB, t. 10, Kraków 1962, s. 231-232. 
Z kolei żądania przywrócenia władzy hetmanom wysunęli wojewoda brzesko-kujawski Antoni Dąmbski, kasztelan brzesko-kujawski Paweł Dąmbski i kasztelan czernihowski Ludwik Bożydar Podhorodeński. W obronie przywilejów prowincji pruskiej stanowczo pisali Michał Czapski i Paweł Dąmbski. Rozwiązania rządzącej krajem konfederacji i przywrócenia liberum veto domagali się hetman wielki koronny Jan Klemens Branicki, hetman wielki litewski Michał Massalski, wojewoda łęczycki Tomasz Sołtyk, obaj Dąmbscy, Ludwik Bożydar Podhorodeński, kasztelan przemęcki Rafał Gurowski, następnie wojewoda rawski Kazimierz Granowski, który z ramienia króla opiekował się w 1766 r. sejmikiem rawskim, a także zwolennik monarchy kasztelan wiślicki Roch Michał Jabłonowski. Po myśli Stanisława Augusta wypowiedział się jedynie kasztelan inowrocławski Jan Skarbek. Ta postawa wroga konfederacji, będącej narzędziem służącym wprowadzaniu reform, zaprezentowana także przez osoby kojarzone z kręgiem prokrólewskim, wskazuje, że wizje państwa monarchy i poddanych w roku 1766 r. znacznie od siebie odbiegały. Przeciwko dysydentom wypowiedzieli się Skarbek oraz Tomasz Sołtyk. Rafał Gurowski z kolei zalecił zezwolić im jedynie na naprawę istniejących świątyń. $\mathrm{Na}$ pełną tolerancję przystał tylko Jabłonowski. Prawie wszyscy senatorowie poparli projekt aukcji wojska, choć wyobrażali ją sobie w różny sposób. Repnin był zaniepokojony aprobatą dla powiększenia armii, rozwiązania konfederacji i antydysydenckim nastawieniem senatorów świeckich ${ }^{70}$.

Opozycja sięgnęła także po publicystykę. Poruszenie na Litwie wywołało pismo pt. „Uwagi dobrego patrioty do sejmów następujących i instrukcji posłom". Kolportowane było jako anonimowe, choć wyszło spod pióra biskupa wileńskiego Józefa i hetmana Michała Massalskich. Ich postulaty były wymierzone w reformy, a chcąc podgrzać nastroje, sugerowali, że król zamierza na nadchodzącym sejmie znieść poddaństwo. Już w maju Jabłonowski donosił monarsze o tego rodzaju pogłoskach krążących na prowincji ${ }^{71}$. Problem uwolnienia chłopów pojawił się także w piśmie referendarza litewskiego Gerwazego Ludwika Oskierki, którego nie można zaliczyć do opozycji ${ }^{72}$. Dwór starał się przeciwdziałać szkodliwej agitacji ${ }^{73}$. Regent litewski Roszkowski został skazany na karę wieży

70 Z. Zielińska, Polska w okowach, s. 473.

71 R.M. Jabłonowski do Stanisława Augusta, 28 V 1766, M. Lit., s. 174-177.

72 O jego autorstwie świadczyła odręczna adnotacja królewska na jednym z egzemplarzy pisma. List na sejmiki G. Oskierki, BC 679, s. 515-517; J. Michalski, Propaganda konserwatywna w walce z reforma w początkach panowania Stanisława Augusta, PH 43, 1952, 3-4, s. 539.

${ }^{73}$ Stanisław August do M. Czartoryskiego, 12 VIII 1766, BC 659, s. 354-355; M. Czartoryski do Stanisława Augusta, 18 VIII 1766, BC 659, s. 361-363. 
i wysokiej grzywny, ponieważ wysłał gazetę pisaną do Grodna, „w której wyraził niektóre baśnie, jakoby na przyszłym sejmie układano projekta zniesienia poddaństwa i pańszczyzny"74. Wyrok miał odstraszyć innych. Opozycja odniosła jednak sukces, bo aż dziewięć instrukcji (nie tylko litewskich) przestrzegało przed zniesieniem poddaństwa ${ }^{75}$.

Aby uzyskać obraz tego, jak kształtował się układ sił na poszczególnych sejmikach, trzeba przyjrzeć się ich przebiegowi oraz instrukcjom, w które zaopatrzono posłów. Podzieliłam zgromadzenia na koronne i litewskie, na końcu omawiając Inflanty. W obrębie tego podziału zachowałam hierarchiczny układ ziem charakterystyczny dla Rzeczypospolitej XVIII w.

$\mathrm{Na}$ sejmiku województwa krakowskiego w Proszowicach interesy dworu reprezentował kasztelan wojnicki Stanisław Dembiński, a wspierali go marszałek konfederacji województwa krakowskiego Aleksander Łętowski oraz chorąży przasnyski Wojciech Kluszewski. Prywatnymi interesami od służby wymówił się natomiast koniuszy wielki koronny Hieronim Wielopolski ${ }^{76}$. W trakcie obrad, którym przewodził Łętowski, odczytano listy pasterskie Sołtyka, Ostrowskiego, ocenzurowany Łubieńskiego, następnie Franciszka Salezego Potockiego („rekomendował tylko siebie i swoją osobę", a także syna), proboszcza mitawskiego Michała Moszyńskiego oraz misjonarza Jazdowskiego z Kurlandii ${ }^{77}$. Dwa ostatnie pisma spotęgowały nastroje antydysydenckie. Dużą rolę w podburzeniu umysłów odegrał krajczy koronny Adam Małachowski. Niespodziewanie dla obozu królewskiego ten siedemdziesięcioletni szlachcic skutecznie zabiegał o funkcję poselską i doprowadził do głosowania, które zatwierdziło antykrólewską i antydysydencką instrukcję ${ }^{78}$. Wielopolski winą za przebieg sejmiku obarczał Łętowskiego i Dembińskiego oraz obiecał „szukać” na krajczego kondemnaty, aby usunąć go z izby poselskiej. Król, niezadowolony z wyboru Małachowskiego i z instrukcji, zaaprobował ów pomysł, a główną przyczynę niepowodzenia upatrywał w braku czujności obu obwinionych ${ }^{79}$. Poza krajczym posłami zostali starosta sądecki Stanisław Małachowski, starosta biecki Stanisław Siemieński, sędzia ziemski

74 Zieliński do J. Mniszcha, 6 VIII 1766, BC 3861, s. 327-329; NN do J. Mniszcha, 6, 13 VIII 1766, BC 3861, s. 331-334, 339-341.

75 Bielska, bracławska, brzeska, drohicka, mścisławska, pińska, ruska, sieradzka, starodubowska.

76 Stanisław August do S. Dembińskiego, 12 VIII 1766, BC 795.

77 W. Kluszewski do Stanisława Augusta, 29 VIII 1766, AGAD, ZP 121, k. 60-64; List ks. Jazdowskiego, AGAD, APP 313, t. 2, s. 282-283; M. Moszyński do bp. A. Krasińskiego, VII 1766, BC 836.

78 W. Kluszewski do Stanisława Augusta, 26 i 29 VIII 1766, AGAD, ZP 121, k. 60-64.

${ }^{79}$ H. Wielopolski do Stanisława Augusta, 3 IX 1766, BC 692; Stanisław August do H. Wielopolskiego, 9 IX 1766, BC 795. 
Stanisław Ścibor Kotkowski, generał Piotr Ożarowski, chorąży koronny Karol Wielopolski, podkomorzy krakowski Stanisław Łętowski oraz Wojciech Kluszewski ${ }^{80}$. Stronnikami Familii byli ten ostatni, Ożarowski oraz być może Wielopolski ${ }^{81}$. Choć Małachowski w przeszłości współpracował z Familią ${ }^{82}$, to jednak jego ambicje poselskie oraz starosty bieckiego utrudniły regalistom panowanie nad obradami ${ }^{83}$. Aleksander Łętowski osobiście ręczył u króla za Siemieńskiego oraz za swego krewnego Stanisława, który w 1764 r. był kojarzony z partią hetmańską ${ }^{84}$. Potencjalnie sześciu na ośmiu posłów mogło więc być stronnikami króla na sejmie.

W księstwie zatorskim i oświęcimskim zgodnie z wolą Stanisława Augusta mandat otrzymał wojski zatorski Ignacy Bobrowski. Drugim posłem został wojski mniejszy krakowski Spytek Jordan ${ }^{85}$.

Nad przebiegiem sejmiku wielkopolskiego w Środzie, tradycyjnym miejscu obrad tamtejszej szlachty ${ }^{86}$, z ramienia króla czuwali starosta czerwonogrodzki Kazimierz Raczyński, kasztelan poznański Jan Klemens Mielżyński oraz znani dotychczas jako malkontenci: Ignacy Twardowski oraz wojewoda poznański Antoni Jabłonowski ${ }^{87}$. Przegraną walkę

80 „Series posłów na seym ekstraordynaryjny warszawski roku 1766”, AGAD, ZP 121, k. 32-42. Jest to źródło, z którego korzystałam przy identyfikacji wszystkich posłów; zaznaczam w tym miejscu jego rolę i nie będę powielała tego źródła w kolejnych przypisach odnoszących się do poszczególnych sejmików. Urzędnicy t. 4, z. 2, s. 53, 82, 95; Urzędnicy t. 10, s. 29; A. Zahorski, Małachowski Stanisław, PSB, t. 19, Kraków 1974, s. $415-420$.

${ }^{81}$ Z. Zielińska, Ożarowski Piotr, PSB, t. 24, Wrocław 1979, s. 673-679; K. Kuras, Wspótpracownicy i klienci Augusta A. Czartoryskiego w czasach saskich, Kraków 2010, s. 156-158, 258; M. Czeppe, Kamaryla Pana z Dukli. Kształtowanie się obozu politycznego Jerzego Augusta Mniszcha, 1750-1763, Warszawa 1998, s. 118. O związkach Wielopolskich z Czartoryskimi: J. Dygdała, Przebendowski Ignacy Franciszek, PSB, t. 28, Kraków 1984-1985, s. 644-647.

${ }^{82}$ M. Czeppe, op. cit., s. 120-121.

${ }^{83}$ H. Wielopolski do Stanisława Augusta, 3 IX 1766, BC 692.

84 Stanisław August do H. Wielopolskiego, 9 IX 1766, BC 795. O Stanisławie Łętowskim: M. Czeppe, op. cit., s. 80, 115-120, 132, 245; T. Szwaciński, op. cit., s. 23; H. Dymnicka, Łętowski Stanisław h. Ogończyk (zm. 1776), PSB, t. 18, Kraków 1973, s. 365-367; K. Przyboś, Sejmik województwa krakowskiego w czasach saskich (1697-1763), Kraków 1981, s. 91

85 Stanisław August do H. Wielopolskiego, 30 VII 1766, BC 795; Urzędnicy t. 4, z. 2, s. $116,162$.

${ }^{86}$ M. Zwierzykowski, Samorząd sejmikowy województw poznańskiego i kaliskiego w latach 1696-1732, Poznań 2010, s. 29; M. Zwierzykowski, E. Tacka, Miejsca obrad sejmików województwa Wielkopolski właściwej od XVI do XVIII wieku, „Res Historica” 42, 2006, s. 8788; M. Zwierzykowski, Akta sejmikowe województw poznańskiego i kaliskiego. Lata 1733-1763, Warszawa 2015.

87 Stanisław August do M. Gliszczyńskiego, 7 VIII 1766, BC 795; Stanisław August do K. Raczyńskiego, 14 VII 1766, BC 795; J. Dygdała, Raczyński Kazimierz, PSB, t. 29, Kraków 1986, s. 644-653. 
o instrukcję dworscy współpracownicy tłumaczyli „trwożliwoś[cią] o religię i podatki" 88 , którą spotęgował list Sołtyka na sejmiki. Raczyński skarżył się, że miał problem z zebraniem kompletu posłów, wszyscy bowiem obawiali się, „by się nie narazić”, ponieważ w Warszawie nie ma „jedności" 99 . Wojewoda smoleński Piotr Sapieha winnymi porażki uznał przedstawicieli króla w Środzie i proponował unieważnić sejmik ${ }^{90}$, ale ocena ta wynikała z rywalizacji z Raczyńskim o wpływy w Wielkopolsce $^{91}$. Król negatywnie ustosunkował się do pomysłu Sapiehy i starał się pogodzić zwaśnionych ${ }^{92}$. Biskup poznański Teodor Czartoryski upewnił monarchę o wierności pomówionych. Sam nie był obecny na sejmiku, zapewne chcąc uchylić się od agitacji na rzecz dysydentów ${ }^{93}$. Zdaniem Repnina postulaty na rzecz niekatolików przepadły przez ludzi biskupa ${ }^{94}$. Posłami z województwa poznańskiego zostali kuchmistrz koronny Adam Poniński, podkomorzy brzesko-kujawski Józef Łącki, starosta koniński Józef Mycielski, kasztelan gnieźnieński Franciszek Miaskowski, starosta stawiszyński Stanisław Łuba i starosta dembski Kazimierz Radoński. Województwo kaliskie reprezentował pisarz wielki koronny Władysław Gurowski, podstoli kaliski Józef Suchorzewski, podsędek wschowski Ludwik Herstopski, regimentarz Krzycki, kasztelanic lędzki Adam Kwilecki oraz pułkownik Rossen. Ponińskiego i Łubę można zakwalifikować jako opozycjonistów. Raczyński usprawiedliwiał wybór Łąckiego i Suchorzewskiego brakiem lepszych kandydatów, więc nie do końca byli po myśli króla. Gurowski od 1762 r. należał do wiernych stronników Familii, a Herstopski i Krzycki to dawni protegowani wojewody Sapiehy ${ }^{95}$.

Województwo sandomierskie na sejmie reprezentowali strażnik wielki koronny książę Stanisław Lubomirski, sędzia ziemski sandomierski Maksymilian Zborowski, kasztelanic elbląski (Jakub lub Józef) Przebendowski, sędzia ziemski radomski Andrzej Święcicki, podczaszy stężycki Łukasz Bętkowski, stolnik radomski Franciszek Libiszewski i miecznik

${ }^{88}$ A. Jabłonowski do Stanisława Augusta, 28 VIII 1766, BC 665, s. 223-224. O roli czopowego i szelężnego w Wielkopolsce, M. Zwierzykowski, Komisja skarbowa poznańska. Z dziejów sejmikowej administracji i sądownictwa skarbowego w Wielkopolsce w XVII i XVIII wieku, Poznań 2003, s. 72-73, 86-93.

${ }^{89}$ K. Raczyński do Stanisława Augusta, 28 VIII 1766, BC 684.

90 P. Sapieha do Stanisława Augusta, 30 VIII 1766, BC 687, s. 29-31.

${ }^{91}$ M. Czeppe, op. cit., s. 49-152.

92 Stanisław August do P. Sapiehy, 1 IX 1766, BC 795; Stanisław August do K. Raczyńskiego, 10 IX 1766, BC 795.

93 T. Czartoryski do Stanisław Augusta, 27 VIII 1766, BC 659, s. 365-367.

${ }_{94}$ M.C. Łubieńska, op. cit., s. 92.

95 K. Raczyński do Stanisława Augusta, 28 VIII 1766, BC 684; Urzędnicy t. 1, z. 2 , s. 73, 180; M. Czeppe, op. cit., s. 148, 154. 
chęciński Jan Skarbek Radoński ${ }^{96}$. Sandomierską szlachtę antydysydencko nastawiał tamtejszy wojewoda Jan Wielopolski ${ }^{97}$. Sołtyk wyrażał niezadowolenie z przebiegu sejmiku, w osiągnięciu sukcesu miał mu przeszkodzić Stanisław Lubomirski ${ }^{98}$. Jednocześnie Repnin także wyrażał dezaprobatę, ponieważ w instrukcji zabrakło punktu na rzecz dysydentów ${ }^{99}$. Zatem być może niezadowolenie hierarchy wynikało z obsady mandatów, gdyż ta nie dała malkontentom przewagi?

Bracia Małachowscy: starosta ostrołęcki Antoni i referendarz koronny Jacek starli się w Szadku z silną opozycją antykrólewską, której źródłem był kasztelan sieradzki Jan Mączyński, „nieukontentowany, że nie wziął ascensu województwa sieradzkiego"100. Ferment siały także pisma Ostrowskiego i Sołtyka oraz działania podkomorzego sieradzkiego Tomasza Błeszyńskiego i starosty nieszawskiego Mogilnickiego ${ }^{101}$. Małachowscy porzucili walkę o instrukcję, skupiając się na wyborze posłów ${ }^{102}$. Mandaty otrzymali stronnicy dworu Jacek Małachowski, starosta sieradzki Stanisław Kossowski, chorąży szadkowski Jan Nepomucen Walewski ${ }^{103}$, a także o nieznanych poglądach stolnik radomszczański Maksymilian Turski. Z ziemi wieluńskiej posłami zostali raczej sprzyjający malkontentom sędzia ziemski wieluński Antoni Stanisław Morzkowski oraz podczaszy ostrzeszowski Andrzej Niemojewski ${ }^{104}$.

Województwo łęczyckie reprezentowali w Warszawie bliski władcy podskarbi nadworny koronny Roch Kossowski, podsędek ziemi łęczyckiej Wojciech Ostrowski, starosta wartelski Teodor Dzierzbicki oraz kasztelanic łęczycki Anastazy Walewski ${ }^{105}$.

96 Urzędnicy t. 4, z. 3, s. 223.

97 M.C. Łubieńska, op. cit., s. 91.

${ }^{98}$ Bp K. Sołtyk do J. Mniszcha, 30 VIII 1766, BC 3861, s. 375-376.

99 Z. Zielińska, Polska w okowach, s. 477.

100 J. Małachowski do J. Ogrodzkiego, 1 IX 1766, BC 672, s. 39.

101 W przeszłości podejmowali już współpracę z Mniszchem, M. Czeppe, op. cit., s. 156-160, 162, 165-166, 255; niejasne, czy chodziło o Józefa, czy o jego syna Ignacego, Z. Zielińska, Mogilnicki Józef Teodor, PSB, t. 21, Kraków 1976, s. 562-563.

102 J. Małachowski do J. Ogrodzkiego, 1 IX 1766, BC 672, s. 39.

103 M. Kobierecki, Walewscy herbu kolumna w XVII-XVIII wieku. Genealogia, majętność, działalność polityczna, Łódź 2008, s. 69-70.

104 Urzędnicy t. 2, z. 2, s. 129, 172, 187, 278; B. Krakowski, Kossowski Stanisław, PSB, t. 14, Wrocław 1968-1969, s. 319-320; W. Szczygielski, Morzkowski Antoni, PSB, t. 22, Warszawa 1977 , s. $25-28$.

105 B. Krakowski, Kossowski Roch, h. Dołęga, PSB, t. 14, s. 317-319; W. Szczygielski, Ostrowski Wojciech, PSB, t. 24, s. 591-592; Prawa konstytucye i przywileie Królestwa Polskiego $i$ Wielkiego Xięstwa Litewskiego y wszystkich prowincji należacych: na walnych seymach koronnych od seymu wiślickiego roku pańskiego 1347 aż do ostatniego seymu uchwalone, Warszawa 1782 (VL 7), s. 252; B. Kobierecki, op. cit., s. 121. 
Na sejmiku województw kujawskich w Radziejowie przeciwko dysydentom agitował kasztelan Jan Skarbek ${ }^{106}$. Mandaty zaś z brzesko-kujawskiego otrzymali sprzyjający władcy sekretarz koronny Antoni Kossowski oraz generał adiutant Jan Chrzciciel Dąmbski, a z województwa inowrocławskiego chorąży brzesko-kujawski Wincenty Modliński oraz zwolennik królewski sędzia ziemski kujawski Wacław Przyłubski107. Z ziemi dobrzyńskiej posłowali stronnicy Familii podczaszy rypieński Piotr Sumiński oraz stolnik dobrzyński Tomasz Rokitnicki ${ }^{108}$.

Przedstawiciel króla podkomorzy łucki Celestyn Czaplic za niepowodzenie na sejmiku kijowskim obarczył opozycyjne nastroje szlachty podsycane przez podczaszego koronnego Feliksa Czackiego i Michała Wielhorskiego, którzy do Żytomierza przesłali punkty uchwalone na sejmiku wołyńskim ${ }^{109}$. Działali oni w województwach ukrainnych, gdzie rozsiewali pogłoski o swojej spodziewanej obecności na kolejnych sejmikach, aby zdezorientować regalistów oraz ośmielić opozycję do działania ${ }^{110}$. W Żytomierzu posłami zostali starosta czerkaski Hieronim Sanguszko, książę Kasper Lubomirski, podkomorzy łucki Czaplic, starosta owrucki Franciszek Zagórski, starosta szawulski Onufry Bierzyński oraz starosta niżyński Wojciech Szuyski ${ }^{111}$. Za stronnika dworu mógł uchodzić tylko Czaplic.

$\mathrm{Na}$ sejmiku generalnym ziem ruskich w Sądowej Wiszni pod laską księcia generała Adama Czartoryskiego z ziemi lwowskiej posłowali zwolennicy dworu podstoli koronny Aleksander Borzęcki oraz generał adiutant królewski Jan Drohojowski, z powiatu żydaczowskiego sam generał ziem podolskich, z ziemi przemyskiej kasztelanic chełmski Antoni Krasicki, z sanockiej zaś tamtejszy podstoli Franciszek Bukowski razem z cześnikiem i sędzią sanockim Józefem Bobowskim ${ }^{112}$. Znamienne, że instrukcja na sejmiku kontrolowanym przez Familię zawierała antydysydencki punkt ${ }^{113}$.

106 M.C. Łubieńska, op. cit., s. 92.

107 Urzędnicy t. 6, z. 2, s. 251; J. Dygdała, Przyłubski Wacław, PSB, t. 29, s. 204.

108 B. Krakowski, Kossowski Antoni, PSB, t. 14, s. 309-311; W. Konopczyński, Dąmbski Jan Chrzciel z Lubrańca, PSB, t. 5, Kraków 1939-1946, s. 33; J. Dumanowski, Sumiński Piotr, PSB, t. 45, Warszawa 2007-2008, s. 603-607.

109 M. Wielhorski do J. Mniszcha, 29 VIII 1766, BC 3861, s. 371-373.

110 C. Czaplic do Stanisława Augusta, 22 VIII 1766, BC 658, s. 221-224; M.J. Piaskowski do J. Ogrodzkiego, 21 VIII 1766, BC 654.

111 E. Orman, Sanguszko Hieronim, PSB, t. 34, Kraków 1992-1993, s. 484-488; W.A. Serczyk, H. Wereszycka, Lubomirski Kasper, PSB, t. 18, s. 28-30; Urzędnicy t. 3, z. 4, s. 87, 100.

112 T. Szwaciński, op. cit., s. 32. Antoni jako jedyny z pięciu braci Ignacego Krasickiego nie obrał kariery duchownej, Z. Goliński, Krasicki Ignacy Błażej Franciszek, PSB, t. 15, Kraków 1970, s. 144-150; Urzędnicy t. 3, z. 1, s. 261, 285; Urzędnicy t. 10, s. 135.

113 AGZ, t. 23, s. 514-518. 
Posłem z Halicza miał zostać cześnik koronny Tadeusz Dzieduszycki, któremu w wyniku procesu z Katarzyną Kossakowską groziła kondemnata ${ }^{114}$. Kasztelanowa nie chciała wycofać oskarżeń, ponieważ wiedziała, że Dzieduszycki miał zostać marszałkiem sejmu. Czartoryscy, choć nie popierali tej kandydatury, stanęli w obronie cześnika. Król odczuwał satysfakcję, ponieważ to wsparcie przeczyło słuchom o konflikcie w obozie władzy, co usiłowała wykorzystać opozycja, a sama kasztelanowa obiecała dostosować się do próśb Augusta Czartoryskiego ${ }^{115}$. Pomimo że na sejmiku doszło do starcia zwolenników z przeciwnikami Dzieduszyckiego, ten zapanował nad obradami i został posłem. Opozycji pozostało wnieść skargę do grodu ${ }^{116}$. Poza cześnikiem mandat otrzymali przyjaciel króla łowczy koronny Franciszek Ksawery Branicki, chorąży halicki Jan Jacek Tarnowski, protegowany władcy pułkownik husarski Franciszek Ksawery Sapieha oraz jego zwolennik sędzia halicki Stanisław Worcell. Z ziemi chełmskiej na sejm posłowali podkomorzy chełmski Józef Bąkowski oraz starosta hadziacki Tadeusz Przyłuski, a w instrukcji pojawił się punkt antydysydencki ${ }^{117}$.

Pieczę nad sejmikiem wołyńskim sprawował podkomorzy krzemieniecki Mikołaj Junosza Piaskowski. Wbrew życzeniu monarchy Michał Wielhorski i Feliks Czacki zostali posłami z Łucka, a w zabiegach kuchmistrza o mandat król domyślił się intrygi Jerzego Mniszcha ${ }^{118}$. Do ustępstw zmusiła Piaskowskiego popularność opozycjonistów wśród miejscowej szlachty oraz presja ze strony Adama Małachowskiego i Franciszka Salezego Potockiego ${ }^{119}$. Poza tym mandaty otrzymali podkomorzy krzemieniecki, kasztelanic żarnowski Józef Stempkowski, hrabia Amor Tarnowski oraz królewski protegowany, sędzia ziemski łucki Józef Stecki. O ich

114 T. Dzieduszycki do J. Ogrodzkiego, 2 i 9 VIII 1766, BC 660, s. 174-175, 301-303; VL 7, s. 42.

115 T. Dzieduszycki do J. Ogrodzkiego, 9 VIII 1766, BC 660, s. 301-303; Stanisław August do T. Dzieduszyckiego, 31 VIII 1766, BC 660, s. 309-311.

116 M. Wielhorski do J. Mniszcha, 29 VIII 1766, BC 3861, s. 371-373; Manifest przeciwko Dzieduszyckiemu, AGAD, ZP 121, k. 107-108.

117 Urzędnicy t. 3, z. 1, s. 38, 64; M. Czeppe, op. cit., s. 129; Urzędnicy t. 3, z. 2, s. 218; W. Szczygielski, Przyłuski Tadeusz, PSB, t. 29, s. 212-214; R. Kozyrski, Duchowieństwo, kościoły i religia $w$ dokumentach sejmików województwa ruskiego w epoce konfesjonalizacji Rzeczypospolitej Obojga Narodów 1648-1768, Lublin 2013, s. 99.

118 Stanisław August do M. Czartoryskiego, 7 VIII 1766, BC 659, s. 353-354; I. Twardowski do J. Mniszcha, 21 VIII 1766, BC 3861, s. 343-346.

119 M. Wielhorski do J. Mniszcha, 9 III, 29 VIII 1766, BC 3861, s. 171-177, 371-373; M.J. Piaskowski do J. Ogrodzkiego, 30 VIII 1766, BC 654. Potocki i Małachowski mieli naciskać na Piaskowskiego, żeby zapewnił temu drugiemu mandat z Łucka, M.J. Piaskowski do J. Ogrodzkiego, 21 VIII 1766, BC 654. 
wierności Piaskowski zapewniał króla ${ }^{120}$. Instrukcja wołyńska stanowiła owoc trudnych negocjacji Piaskowskiego i podkomorzego koronnego Kazimierza Poniatowskiego z Czackim oraz Wielhorskim. Nastroje antydysydenckie wspierały listy Wacława Rzewuskiego oraz Erazma Wołłowicza $^{121}$. Poniatowski, ujawniając rosyjskie naciski w sprawie dysydenckiej, starał się chronić króla przed atakami opozycji. W rozmowach z Piaskowskim i Poniatowskim Wielhorski oraz Czacki zgodzili się, że „posłowie w prywatnych domach, na prywatne nabożeństwa pozwolą, ale bez śpiewania, bez dzwonienia, bez kazań i najmniejszych nauk"122. W istocie liczyli, że na sejmiku „może jeszcze co się doda dla ubezpieczenia wiary zniósłszy się z innymi obywatelami" ${ }^{123}$. Kuchmistrz nie uległ zatem ekonomicznej propagandzie związanej z kwestią dysydencką ${ }^{124}$ a jego ustępstwo było jedynie pozorne.

Z województwa podolskiego na sejm pojechali oponenci dworu starosta drohobycki Józef Rzewuski i starosta smotrycki Teodor Potocki, poza tym zwolennik króla starosta wyszyński Feliks Łoś oraz kojarzony z dworem starosta woroniecki książę Aleksander Światopełk Czetwertyński i stolnik czerwonogrodzki Kazimierz Wykowski wraz z podczaszym podolskim Piusem Franciszkiem Boreyką ${ }^{125}$.

Na sejmiku lubelskim marszałkiem został Michał Kostka Nieprzecki. W czasie obrad podkomorzy lubelski Tomasz Dłuski przeforsował przy użyciu siły królewskich kandydatów na posłów, dlatego opozycja, której przewodził Antoni Lubomirski ${ }^{126}$, złożyła protestację do grodu ${ }^{127}$. To samo po sejmiku uczynili zwolennicy króla, oskarżając oponentów, że wbrew wcześniejszym ustaleniom „po zgodnym posłów obraniu” dopisali punkty do laudum i instrukcji oraz wybrali posłów do króla oraz

120 Stanisław August do J. Steckiego, 12 VIII 1766, BC 795; M.J. Piaskowski do J. Ogrodzkiego, 30 VIII 1766, BC 654.

${ }_{121}$ M. Wielhorski do J. Mniszcha, 29 VIII 1766, BC 3861, s. 371-373.

122 M. Wielhorski do J. Mniszcha, 22, 29 VIII 1766, BC 3861, s. 362, 371-373.

${ }^{123}$ M. Wielhorski do J. Mniszcha, 22 VIII 1766, BC 3861, s. 362. Ostatecznie w instrukcji znalazł się punkt potwierdzający status quo w sprawie dysydenckiej, instrukcja wołyńska, AGAD, ZP 121, k. 79-85.

124 J.J. Głowacki, op. cit., s. 109.

125 Z. Zielińska, Rzewuski Józef, PSB, t. 34, s. 112-113; W. Szczygielski, Potocki Teodor, PSB, t. 28, s. 213-216; idem, Łoś Feliks, PSB, t. 18, s. 429-431; J. Nieć, Czetwertyński-Światopełk Aleksander, PSB, t. 4, Kraków 1938, s. 357-358; H. Waniczkówna, Boreyko Pius Franciszek, PSB, t. 2, Kraków 1936, s. 325.

126 T. Dłuski do J. Ogrodzkiego, 9 IX 1766, BC 660, s. 159-161; T. Dłuski do Stanisława Augusta, 3 IX 1766, BC 660, s. 157-158.

127 W. Bednaruk, Sejmiki lubelskie w okresie stanisławowskim (1764-1794), Lublin 2011, s. 139 . 
prymasa, zaopatrując ich w instrukcje o nieznanej treści ${ }^{128}$. Ostatecznie konflikt zażegnano i nikt nie poniósł konsekwencji ${ }^{129}$. Mandaty uzyskali Dłuski, chorąży lubelski Stanisław Wybranowski, z powiatu łukowskiego skarbnik łukowski Jacek Jezierski, cześnik łomżyński Adam Szaniawski, z kolei z powiatu urzędowskiego starosta wąwolnicki Stanisław Małachowski oraz kasztelanic lubelski i starosta trześniowski Andrzej Tarło ${ }^{130}$. Jezierski firmował nazwiskiem zarówno laudum, jak i instrukcję, ale nie manifest regalistów. Do opozycjonistów można zaliczyć także starostę wąwolnickiego, syna Adama Małachowskiego. Cień podejrzenia na Szaniawskiego rzucają jego bliżej nieokreślone interesy z młodym Małachowskim $^{131}$.

Opiekę nad sejmikiem bełskim król powierzył kasztelanowi buskiemu Ewarystowi Kuropatnickiemu oraz aktywnemu w kampanii sejmikowej Kazimierzowi Poniatowskiemu ${ }^{132}$. Ten starał się zawczasu poufnie ustalić treść instrukcji bełskiej. Postulował, aby każdy „oprócz z królewszczyzny, kwarty na wojsko dawał piąty grosz od prowizji”, żeby deputatów wybierano po jednym z województwa i wyznaczano im pensję, a trybunał zbierał się „raz w Piotrkowie, drugi raz w Lublinie, trzeci we Lwowie” i miał stały skład sędziowski. Ponadto w czasie obrad zaproponował płacenie placowego przez szlachtę, która miała „swoje dworki w królewszczyznach", następnie wynagrodzenie królowi kosztów poniesionych na utworzenie Szkoły Rycerskiej, otwarcie mennicy oraz remont twierdzy w Kamieńcu Podolskim. Poniatowski wnioskował także o swobodę kultu dla innowierców, przeciwko czemu protestował starosta połczyński Franciszek Świeżawski. Ostatecznie uległ on, zastrzegając, aby żądania nie wzrosły. Podczas obrad odczytano antydysydencki list biskupa Wołłowicza. Gdy na forum sejmikowe wniesiono sprawę dysydencką, w formie uprzednio ustalonej, opór szlachty skłonił Kuropatnickiego do odłożenia sprawy na następny dzieńn ${ }^{133}$. Ostatecznie w instrukcji pojawił się punkt na rzecz innowierców. Posłów wybrano szybko i jednomyślnie.

128 Manifest lubelski, AGAD, ZP 121, k. 109-111.

129 W. Bednaruk, op. cit., s. 139.

130 Laudum woj. lubelskiego, BC 8326, s. 296-298; Urzędnicy t. 4, z. 4, s. 20, 82; A. Haratym, Szaniawski Adam, PSB, t. 46, Kraków 2010, s. 613-615; Z. Zielińska, Małachowski Adam, PSB, t. 19, s. 386-388.

131 A. Haratym, Szaniawski Adam, s. 613-615.

132 Poniatowski jeszcze trzy dni wcześniej układał się w Łucku z opozycją odnośnie do treści instrukcji. Błędne jest przypuszczenie Głowackiego o jego obecności na obradach szlachty wołyńskiej. 25 sierpnia ów czynnie uczestniczył w sejmiku bełskim. J.J. Głowacki, op. cit., s. 109; NN do J. Mniszcha, 25 VIII 1766, BC 3861 (kopia), s. 359-360.

133 NN do J. Mniszcha, 25 VIII 1766, BC 3861 (kopia), s. 359-360; NN do J. Mniszcha, 25 VIII 1766, BC 3861 (kopia 2), s. 360-362. 
Z bełskiego posłowali Poniatowski, stolnik lubaczewski Makary Kurdwanowski, podkomorzy bełski Adam Chołoniewski, starosta buski Józef Mier oraz starosta grabowiecki Ludwik Wilga. Za regalistów możemy uznać dwóch pierwszych, pozostali trzej byli związani z opozycją ${ }^{134}$.

Województwo płockie na sejmie reprezentowali pisarz wielki koronny August Sułkowski, stolnik sierpski Ignacy Wessel, podstoli płocki Wojciech Kosiński oraz kasztelanic sierpski Józef Niszczycki ${ }^{135}$.

Z województwa mazowieckiego, z ziemi czerskiej posłowali starosta czerski Franciszek Bieliński oraz cześnik piotrkowski Ignacy Rychłowski. Nieco więcej wiadomo o sejmiku warszawskim. Po jego zagajeniu przez związanego z dworem podkomorzego warszawskiego Stanisława Sobolewskiego ${ }^{136}$, Otto Krzysztof de Howen wygłosił mowę w obronie szlachty kurlandzkiej, następnie rozdał pismo pt.: „Objaśnienie spraw kurlandzkich" dotyczące dziejów konfliktu poddanych z księciem Bironem od $1763 \mathrm{r}^{137}$ Wbrew woli dworu tekst został szeroko rozkolportowany po kraju $^{138}$. Posłami zostali bliski królowi chorąży warszawski Teodor Kajetan Szydłowski i podczaszy warszawski Adam Szamocki. Z ziemi wiskiej mandaty otrzymali chorąży wiski Stanisław Opacki oraz pisarz ziemski wiski Antoni Grądzki; z powiatu wyszogrodzkiego przychylny władcy starosta wyszogrodzki Michał Szymanowski oraz podkomorzy wyszogrodzki Cyprian Nakwaski - ten ze względu na swojego ojca był raczej prokrólewski ${ }^{139}$. Z ziemi zakroczymskiej posłowali adherent monarchy pisarz wielki koronny Jacek Ogrodzki i chorąży zakroczymski Michał Kazimierz Szydłowski. Nad sejmikiem ciechanowskim czuwał marszałek konfederacji tej ziemi starosta bobrownicki Franciszek Aleksander Podoski, którego wraz z instygatorem koronnym Janem Chryzostomem Krajewskim król przeznaczył na posłów i obaj pojawili się na sejmie ${ }^{140}$. O przebiegu obrad w Ciechanowie dowiadujemy się z dwóch relacji sporządzonych dla

134 NN do J. Mniszcha, 25 VIII 1766, BC 3861 (kopia), s. 359-360; M. Czeppe, op. cit., s. 134-135, 144-145. Twardowski jeszcze przed sejmikiem przesłał Mniszchowi listę osób, które otrzymają mandat z ziemi bełskiej. Zamiast Wilgi podał niejakiego Głogowskiego, I. Twardowski do J. Mniszcha, 21 VIII 1766, BC 3861, s. 343-346; Urzędnicy t. 3, z. 2, s. 49, 88, 99, 111 .

135 D. Dukwicz, M. Zwierzykowski, Sułkowski August, PSB, t. 45, s. 542-553; VL 7, s. 128.

136 D. Dukwicz, Sobolewski Stanisław z Piętek, PSB, t. 39, Kraków 1999-2000, s. 590-591.

137 Objaśnienie praw kurlandzkich, AGAD, Zbiór Tyzenhauzów, E-494, s. 126-137.

138 NN do J. Mniszcha, 27 VIII 1766, BC 3861, s. 363-365; Protokół, 19 VIII 1766, s. $427-428$.

139 Z. Zielińska, Szymanowski Michał, PSB, t. 50, Warszawa 2014, s. 98-99; W. Szczygielski, Nakwaski Cyprian, PSB, t. 22, s. 478-479.

140 Stanisław August do F.A. Podoskiego, 31 VII 1766, BC 795. 
Jerzego Mniszcha i Adama Krasińskiego ${ }^{141}$. Obydwie mówią o rozdwojeniu sejmiku. A zatem protegowani królewscy mieli konkurentów. Trudno określić, czy należeli do regalistów, czy opozycji. Nastroje antykrólewskie pobudził list pasterski Krasińskiego ${ }^{142}$. Na sejmiku powstały dwie instrukcje. Jedną z nich powierzono stolnikowi bracławskiemu Michałowi Kickiemu i pisarzowi ziemi ciechanowskiej Kazimierzowi Górskiemu, którzy nie pojawili się w żadnej ze znanych relacji. Zawierała ona trzy punkty: podziękowanie dla władcy, zgodę na dalsze trwanie konfederacji oraz prośbę o wybicie odpowiedniej ilości nowej monety ${ }^{143}$. Zatem miała regalistyczny charakter. Być może na obu sejmikach obrano rywalizujących z sobą zwolenników króla i to wywołało konsternację na dworze ${ }^{144}$. W Łomży mandaty otrzymali starosta łomżyński Ignacy Przyjemski ${ }^{145}$ oraz podczaszy łomżyński Romuald Wyszkowski. Zdaje się, że pieczę nad sejmikiem różańskim władca powierzył kasztelanowi wiskiemu Kazimierzowi Karasiowi ${ }^{146}$. Posłami z tej ziemi zostali pisarz ziemski zakroczymski Adam Wągrocki oraz protegowany Adama Czartoryskiego wojski różański Wojciech Andrzej Chądzyński, z ziemi zaś liwskiej kojarzony raczej z kręgiem królewskim starosta liwski Ignacy Karczewski oraz starosta zbuczyński Ignacy Cieszkowski. Z ziemi nurskiej posłowali pisarz nurski Adam Kownacki i powiązany z królem pułkownik Tomasz Adam Ostrowski ${ }^{147}$.

$\mathrm{Z}$ województwa podlaskiego szlachta drohicka wysłała na sejm współpracującego z dworem podkomorzego drohickiego Leona Kuczyńskiego oraz raczej opozycyjnie nastawionego starostę drohickiego Aleksandra Ossolińskiego. Z kolei posłami z Bielska zgodnie z zamysłem Michała Czartoryskiego zostali podczaszy bielski Maciej Poletyło i podstoli bielski Stanisław Karwowski ${ }^{148}$. Ziemię mielnicką reprezentowali cześnik mielnicki Józef Markowski oraz plenipotent Czartoryskich podstoli miński Jan Kłokocki ${ }^{149}$.

${ }^{141}$ NN do J. Mniszcha, 27 VIII 1766, BC 3861, s. 363-365; NN do bp. A. Krasińskiego, 26 VIII 1766, BC 836, druga relacja jest uboższa jedynie o pewne szczegóły.

142 Z. Zielińska, Polska w okowach, s. 483.

143 Instrukcja dla Kickiego i Górskiego, AGAD, ZP 121, k. 98-99.

144 Protokół, 29 VIII 1766, s. 445.

145 W. Szczygielski, B. Wojciechowski, Przyjemski Ignacy, PSB, t. 29, s. 175-178.

146 Protokół, 13 VIII 1766, s. 415.

147 A. Czartoryski do bp. A. Krasińskiego, 17 VIII 1766, BC 836; J. Michalski, Karczewski Józef, PSB, t. 12, Warszawa 1967, s. 32-33; T. Kizwalter, Ostrowski Tomasz Adam, PSB, t. 24 , s. 579-583.

148 Urzędnicy t. 8, s. 183, 186; W. Szczygielski, Kuczyński Leon Michał, PSB, t. 16, Warszawa 1971, s. 88-89; H. Dymnicka-Wołoszyńska, Ossoliński Aleksander, PSB, t. 24, s. 388-390; T. Szwaciński, op. cit., s. 39; M. Czartoryski do Stanisława Augusta, 13 VIII 1766, BC 659, s. 357-359.

149 R. Chojecki, Markowski Józef, PSB, t. 20, Warszawa 1975, s. 43-44. 
Z województwa rawskiego, pod opieką tamtejszego wojewody Kazimierza Granowskiego, mandaty po myśli króla otrzymali chorąży chęciński Andrzej Dobiecki i podstoli sochaczewski Kasper Grotowski, z ziemi sochaczewskiej podkomorzy sochaczewski Stanisław Kostka Gadomski oraz kojarzony z dworem pisarz sochaczewski Władysław Mieczyński, natomiast z ziemi gostyńskiej przychylni królowi starosta gostyński Antoni Lasocki oraz chorąży gąbiński Józef Mikorski ${ }^{150}$.

Sejmikiem czernihowskim we Włodzimierzu kierował starosta przyłuski Franciszek Gostyński ${ }^{151}$. Odczytano tam ocenzurowany list prymasa oraz Wołłowicza, a także punkty do instrukcji o wydźwięku antydysydenckim pióra Feliksa Czackiego ${ }^{152}$. Zdaniem Michała Wielhorskiego instrukcja czernihowska miała charakter opozycyjny w większym stopniu niż łucka ${ }^{153}$. Posłami zaś zostali regalista Franciszek Czapski brat Feliksa, sędzia ziemski czernihowski Jan Charzewski, kasztelanic czernihowski Józef Bożydar Podhorodeński oraz wojski lubelski Michał Radzimiński ${ }^{154}$.

Dwór już od sejmu konwokacyjnego dążył do unifikacji Prus Królewskich z Rzecząpospolitą, co spotkało się z oporem zarówno Gdańska, Torunia, Elbląga, jak i pruskiej szlachty. Rozmowy z przebywającymi w Warszawie w maju 1766 r. podkomorzym chełmińskim Antonim Czapskim, wojewodą chełmińskim Franciszkiem Stanisławem Czapskim i kasztelanem chełmińskim Juliuszem Dziewanowskim oraz rezydentami wielkich miast pruskich pokazały natomiast dążenie całej prowincji do likwidacji konfederacji generalnej ${ }^{155}$. Król, zabiegając o przychylność szlachty pruskiej, w przededniu sejmików 1766 r. usunął ze stanowiska znienawidzonego wojewodę pomorskiego Pawła Mostowskiego, powierzając mu w zamian województwo mazowieckie, na jego zaś miejsce powołał Jerzego Fleminga ${ }^{156}$.

Jeśli zaś chodzi o kampanię sejmikową 1766 r., to w Prusach król zlecił jej organizację starostom nakielskiemu Kasprowi Rogalińskiemu,

150 Stanisław August do K. Granowskiego, 12 VIII 1766, BC 795; K. Granowski do Stanisława Augusta, 16 VIII 1766, BC 662; Stanisław August do K. Granowskiego, 18 VIII 1766, BC 795; W. Konopczyński, Gadomski Stanisław Kostka, PSB, t. 7, Kraków 1958, s. $200-$ 202; W. Szczygielski, Mieczyński Władysław, PSB, t. 20, s. 738-739; idem, Lasocki Antoni, PSB, t. 16, s. 537; A. Kociszewski, Mikorski Józef Andrzej, PSB, t. 21, s. 163-164.

${ }^{151}$ NN do J. Mniszcha, 25 VIII 1766, BC 3861 (kopia), s. 359-360.

152 NN do J. Mniszcha, 25 VIII 1766, BC 3861 (kopia 2), s. 360-362.

153 M. Wielhorski do J. Mniszcha, 29 VIII 1766, BC 3861, s. 371-373.

154 M.J. Piaskowski do Stanisława Augusta, 21 i 30 VIII 1766, BC 654; NN do J. Mniszcha, 25 VIII 1766, BC 3861 (kopia), s. 359-360; Urzędnicy t. 6, z. 2, s. 186; W. Szczygielski, Podhorodeński Józef, PSB, t. 27, Kraków 1983, s. 98-99; Urzędnicy t. 4, z. 4, s. 62.

155 Protokół, 12 VII 1766, s. 359; J. Dygdała, Życie polityczne, s. 175-176.

156 J. Dygdała, Życie polityczne, s. 119-128, 173. 
brodnickiemu Karolowi Szmidtowi i podkomorzemu lubelskiemu Tomaszowi Dłuskiemu. Dwaj ostatni działali wśród szlachty, natomiast pierwszy miał skłonić Gdańsk, Toruń oraz Elbląg do poparcia na sejmikach królewskiego programu. Rogaliński w rozmowach z miastami starał się uzyskać ich zgodę na generalne czopowe i szelężne, a ponieważ przez dwa lata nie płaciły one cła generalnego, zasugerował jako rekompensatę naprawę na koszt miast „szpicy montowskiej” rozdzielającej nurt Wisły na Nogat oraz Leniwkę. Starosta forsował punkt pozwalający niekatolikom na swobodny kult w dobrach królewskich, duchownych i ziemskich ${ }^{157}$. Miasta pruskie przyjęły wspólną strategię. Obiecały sfinansować naprawę „szpicy” oraz popierać na sejmiku sprawę dysydencką ${ }^{158}$. Natomiast o czopowym chciały zadecydować dopiero na sejmikach posejmowych. $Z$ jednej strony niwelowało to szanse na przyjęcie podatków, z drugiej potwierdzało tendencje separatystyczne prowincji, gdyż miasta chciały podlegać wyłącznie decyzjom własnego sejmiku ${ }^{159}$. Regalistów nadzieją napawało entuzjastyczne przyjęcie nowego wojewody pomorskiego. Sądzili, że pozyskali Michała Czapskiego, Dziewanowskiego, opata oliwskiego Jacka Rybińskiego (po cichu zabiegał on o pomoc Radziwiłłów w opanowaniu sejmików pomorskich) oraz wpływową, dysydencką rodzinę Goltzów. Rzeczywista skala poparcia była jednak niewielka ${ }^{160}$.

Sejmiki powiatowe w województwie pomorskim odbyły się 1 września $1766 \mathrm{r}$. W powiecie świeckim sukces odniósł dwór, opowiedziano się tam za unifikacją waluty i nowymi podatkami. Pozostałe obrady zdominowała rodzina Jezierskich. Instrukcje przez nich spisane wykluczały wprowadzenie czopowego i szelężnego oraz nakazywały ochronę praw pruskich. Na sejmiku wojewódzkim w Starogardzie (4-5 IX 1766) doszło do starcia dwóch stronnictw - Jezierskich i Goltzów. Przewagę zdobyło to drugie popierane przez Rogalińskiego oraz szlachtę dysydencką. Obrady zagaił Flemming, a marszałkiem był Michał Władysław Lniski. Zgromadzeniu województwa chełmińskiego w Kowalewie przewodniczył kasztelanic gdański Antoni Kruszyński. Instrukcja zawierała żądania rozwiązania konfederacji generalnej i przywrócenia władzy hetmańskiej, a Szmidtowi udało się zapisać jedynie punkt odnoszący się do Szkoły Rycerskiej.

157 St. Achremczyk, Życie sejmikowe Prus Królewskich w latach 1647-1772, Olsztyn 1999, s. 131; K. Rogaliński do J. Ogrodzkiego, 8 VIII, 26 VIII, 29 VIII 1766, BC 685, s. 17-20, 33-36, 37-40.

${ }^{158}$ K. Rogaliński do J. Ogrodzkiego, 27 VII, 8 i 29 VIII 1766, BC 685, s. 13-16, 17-20, $37-40$.

159 J. Dygdała, Życie polityczne, s. 178.

160 Ibidem, s. 166, 180; K. Rogaliński do J. Ogrodzkiego 13 VIII 1766, BC 685, s. 21-24. 
Sejmik malborski w Sztumie zagaił wojewoda Czapski i pokierował nim w duchu antykrólewskim ${ }^{161}$.

Opozycja opanowała także sejmik generalny Prus Królewskich (generał pruski) (9-16 września), któremu marszałkował starosta bielski Antoni Sarnacki. W Malborku skoncentrowano się na utrzymaniu odrębności prawnej Prus, reformie monetarnej, podatkach i cle generalnym. Tubą opozycji był Michał Czapski, wsparty przez Franciszka Stanisława Czapskiego, a ożywioną agitację antydysydencką prowadził biskup Andrzej Baier. W obronie przywilejów gorliwością wykazały się także miasta. Ich liderem był burmistrz toruński Chrystian Klosmann ${ }^{162}$. W gronie senatorów umiarkowane poglądy reprezentowali kasztelan gdański Józef Pruszak, Dziewanowski, a także miecznik Andrzej Gostomski. Skłaniali się oni do ustępstwa w sprawie podatków, jednak ich stanowisko, podobnie jak i perory Fleminga oraz Antoniego Czapskiego nie przyniosły efektu. Nawet propozycja, aby zapobiec dotychczasowej praktyce psucia przez Gdańsk monety, choć spotkała się z poparciem szlachty, została obwarowana żądaniem zmiany nowo wprowadzonej polskiej stopy menniczej. Wobec oporu sejmikujących zgodzono się na pozostawienie dysydentów przy dotychczasowych prawach i postanowieniach pokoju oliwskiego oraz traktatów welawsko-bydgoskich. Jak tłumaczyli Rogaliński i Szmidt, dawne prawa zapewniały innowiercom wolność sprawowania kultu. Obrady sejmiku generalnego zakończyło przyjęcie laudum przeciwko uchwałom sejmów konwokacyjnego i koronacyjnego. Podziękowano za ochronę praw pruskich m.in. Czapskim i Goltzom.

Rogaliński winą za niepowodzenia stronników dworu w województwie pomorskim obarczał obojętność swoich współpracowników, czym być może chciał usprawiedliwić własną nieudolność. Dłuski zaś umniejszał porażkę, zapewniając, że na 42 wybranych posłów zaledwie czterech można uznać za niepewnych. Badania Jerzego Dygdały wykazały, że połowę wybranych na sejm stanowili ludzie dotąd niezaangażowani politycznie. Aż 16 z 42 posłów stanowili malkontenci, jedynie 4 to regaliści ${ }^{163}$.

Analizę przebiegu sejmików litewskich należy rozpocząć od sejmiku wileńskiego, który był najważniejszy na obszarze Wielkiego Księstwa

${ }^{161}$ J. Dygdała, Życie polityczne, s. 180-181; K. Szmidt do J. Ogrodzkiego, 5 IX 1766, BC 711; K. Rogaliński do J. Ogrodzkiego, 9 IX 1766, BC 685.

162 J. Dygdała, Życie polityczne, s. 181-182; St. Achremczyk, op. cit., s. 143, 158; K. Rogaliński do J. Ogrodzkiego, 12 IX 1766, BC 685; T. Dłuski do Stanisława Augusta, 9 IX, 12 IX 1766, BC 660, s. 159-161, 165.

${ }^{163}$ K. Rogaliński do Stanisława Augusta, 19 IX 1766, BC 685; T. Dłuski do Stanisława Augusta, 16 IX 1766, BC 660, s. 167-168; J. Dygdała, Życie polityczne, s. 185. 
Litewskiego i trzeci w skali Rzeczypospolitej ${ }^{164}$. O przebieg tamtejszych obrad miał zadbać podskarbi wielki litewski Michał Brzostowski. $\mathrm{Z}$ powodu wielu chętnych, posłów obrano dopiero drugiego dnia obrad (26 sierpnia). Mandaty otrzymali ciwun Aleksander Tyszkiewicz i podwojewoda wileński Aleksander Horain ${ }^{165}$. W Wilnie w czasie sejmików przebywał hetman polny litewski Aleksander Sapieha, który agitował zapewne na rzecz przywrócenia prerogatyw buławy, a do wspólnej akcji w tej sprawie w lipcu 1766 r. nakłaniał Jana Klemensa Branickiego ${ }^{166}$. Z kolei z powiatu oszmiańskiego posłami zostali podstarosta oszmiański Antoni Hutorowicz oraz porucznik petyhorski Antoni Joachim Oskierka, z lidzkiego powiązany z Familią chorąży powiatu lidzkiego Franciszek Antoni Aleksandrowicz i marszałkowicz lidzki Antoni lub Dominik Narbutt, z wiłkomierskiego natomiast starosta wiłkomierski Jan Eperyaszy oraz starosta posolski Michał Tyzenhauz. Z sejmiku brasławskiego mandat otrzymał pisarz ziemski brasławski Antoni Prewysza Kwinta oraz cześnik powiatu brasławskiego Antoni Jarocki. Wiadomo, że bezskutecznie o mandat ubiegał się pisarzewicz litewski Robert Brzostowski ${ }^{167}$.

Z województwa trockiego, którego szlachta obradowała w Trokach ${ }^{168}$, na posłów zostali wybrani związany z Familią podkomorzy trocki Andrzej Władysław Uskolski i sędzia ziemski trocki Jan Antoni Wazgi(e)rd ${ }^{169}$. Więcej informacji posiadamy o sejmiku grodzieńskim, który król oddał pod opiekę Antoniemu Tyzenhauzowi. Ten, mając swobodny wybór „kolegi do poselstwa", postarał się, aby mandat otrzymał jego protegowany marszałek grodzieński Tadeusz Jundziłł170. Podskarbi ułożył instrukcję, która z powodu oporu stawianego przez hetmana Massalskiego została przyjęta dopiero drugiego dnia obrad. Opozycji pozostało wnieść do

164 R. Jurgaitis, Funkcjonowanie sejmiku wileńskiego w latach 1717-1795. Między szlacheckim parlamentaryzmem a samorzadem, w: Praktyka życia publicznego w Rzeczypospolitej Obojga Narodów w XVI-XVIII wieku, red. U. Augustyniak, A.B. Zakrzewski, Warszawa 2010, s. 38.

165 M. Brzostowski do Stanisława Augusta, 26 VIII 1766, BC 656, s. 237-240; NN do J. Mniszcha, 25 VIII 1766 z Wilna, BC 3861, s. 355-357; Urzędnicy, Litwa t. 1, s. 93, 164; R. Jurgaitis, „Vilniaus seimelio veikla 1717-1795 m.” (mps doktoratu), s. 167, 181-182.

166 NN do J. Mniszcha, 25 VIII 1766 z Wilna, BC 3861, s. 355-357; Z. Zielińska, Sapieha Aleksander, PSB, t. 34, s. 565-569.

167 M. Złomska, Oskierka Antoni Joachim, PSB, t. 24, s. 357-358; VL 7, s. 79, 82; T. Szwaciński, op. cit., s. 27; Urzędnicy, Litwa t. 1, s. 658; R. Brzostowski do A. Sapiehy, 28 VIII 1766, Biblioteka Wróblewskich, F 139-1993.

168 A.B. Zakrzewski, Sejmiki Wielkiego Księstwa Litewskiego XVI-XVIII w. - ustrój i funkcjonowanie. Sejmik trocki, Warszawa 2000, s. 29.

169 T. Szwaciński, op. cit., s. 28.

170 Stanisław August do M. Brzostowskiego, 14 VIII 1766, BC 656, s. 241. 
grodu skargę ${ }^{171}$. Na życzenie Michała Czartoryskiego sejmikiem kowieńskim kierował łowczy wielki litewski Antoni Zabiełło. Współpraca z nim była niepewna, ponieważ w polityce nie kierował się on sentymentami, ale popierał zawsze silniejszą stronę ${ }^{172}$. Kandydatem kanclerza na posła był wojski kowieński Jan Mejer ${ }^{173}$. Zabiełło, mając wolną rękę co do obsady drugiego mandatu, zadbał, aby do Warszawy pojechał jego podopieczny Szynom Kossakowski ${ }^{174}$. W instrukcji kowieńskiej znalazł się punkt prodysydencki, co król uznał za dowód wierności Zabiełłów, oni zaś sami liczyli przede wszystkim na przysłużenie się Rosji175. Z ziemi upickiej mandat otrzymali wojski upicki Onufry Białłozor oraz marszałek upicki Michał Karol Bitowtt, a instrukcja zawierała prodysydencki punkt ${ }^{176}$.

W sprawie sejmiku żmudzkiego tamtejszy biskup, Jan Dominik Łopaciński, porozumiał się z kasztelanem żmudzkim Michałem Górskim. Obydwaj byli przychylni opozycji ${ }^{177}$. Hierarcha, zażegnawszy konflikt między działającymi zapewne na polecenie Familii piwniczym Franciszkiem Piłsudskim oraz starostą wojnickim Tadeuszem Billewiczem, był spokojny o przebieg sejmiku ${ }^{178}$. Być może źródło animozji stanowiła rywalizacja o pozycję w województwie. Zgodnie z wolą Michała Czartoryskiego posłami zostali Piłsudski, marszałek konfederacji Stanisław Odachowski oraz ciwun twerski Antoni Giełgud ${ }^{179}$. Łopaciński obawiał się o instrukcję, szczególnie o postanowienia dotyczące religii, sam bowiem był

${ }^{171}$ NN do J. Mniszcha, 25 VIII 1766 z Wilna, BC 3861, s. 355-357. Punkt dotyczący dysydentów znalazł się w instrukcji, choć Tyzenhauz uważał, że należałoby tę sprawę załatwić na sejmie bez uprzedniego nagłaśniania; S. Kościałkowski, op. cit., s. 80.

${ }^{172}$ M. Jusupović, Prowincjonalna elita litewska w XVIII wieku. Działalność polityczna rodziny Zabiełłów w latach 1733-1795, Warszawa 2014, s. 44-62, 172-264.

173 M. Czartoryski do A. Zabiełły, 26 III, 14 IV 1766, BC 3880.

174 O związkach Kossakowskiego z Zabiełłami: W. Konopczyński, Kossakowski Szymon Marcin, PSB, t. 14, s. 288-293; V. Dolinskas, Szymon Kossakowski. Dzieje jednej kariery. Znane i nieznane fakty z biografii, „Krakowskie Pismo Kresowe” 3, 2011, s. 79-81; idem, Simonas Kosakovskis. Politiné ir karine veikla Lietuvos Didžiojoje Kunigaikštystėje. 1763-1794, Vilnius 2003, s. 122-124; M. Jusupović, op. cit., s. 135, 136-138, 181-182, 202, 207-208, 242, 260.

175 Stanisław August do A. Tyzenhauza, 26 II 1776, BC 716; M. Jusupović, op. cit., s. $65,262-268$.

176 Urzędnicy, Litwa t. 2, s. 564; Z. Zielińska, Polska w okowach, s. 493.

177 Bp J.D. Łopaciński do M. Łopacińskiego, 26 VII, 2 VIII 1766, LVIA, k. 124-125, 223-224. Hetman Sapieha gościł u biskupa przez tydzień pod koniec czerwca (20-27), skąd odjechał do Wilna, bp J.D. Łopaciński do M. Łopacińskiego, 27 VI 1766, LVIA, k. 215-216.

178 Bp J.D. Łopaciński do M. Łopacińskiego, 9 VIII 1766, LVIA, k. 127-128.

179 Bp J.D. Łopaciński do M. Łopacińskiego, 19 VII, 30 VIII 1766, LVIA, k. 133$134,221$. 
nastawiony wrogo wobec ustępstw dla innowierców ${ }^{180}$. Ostatecznie posłowie żmudzcy jechali do Warszawy z punktem na korzyść dysydentów ${ }^{181}$.

$\mathrm{Na}$ sejmikach egzulanckich smoleńskim i starodubowskim z Michałem Brzostowskim współpracował kasztelan smoleński Tadeusz Burzyński. Z drugiego na sejm jechał instygator litewski Adam Chmara i marszałek wołkowyski Paweł Bułharyn, ze smoleńskiego zaś pułkownik smoleński Stanisław Jakub Eydziatowicz oraz podstoli trocki Michał Feliks Wazgierd, który był protegowanym biskupa wileńskiego ${ }^{182}$.

Z województwa połockiego mandat otrzymał stolnik połocki Jan Buynicki oraz podwojewodzi Kazimierz Ignacy Korsak ${ }^{183}$.

Z województwa nowogródzkiego posłowali zwolennik króla sekretarz wielki litewski Joachim Chreptowicz, a także pisarzewicz ziemski nowogrodzki Samuel Korsak; z powiatu słonimskiego starosta słonimski Florian Brunon Strawiński i stolnik wołkowyski Antoni Dziekoński, natomiast z powiatu wołkowyskiego związany z Familią referendarz litewski Gerwazy Ludwik Oskierka oraz zwolennik króla koniuszy litewski Stefan Olędzki ${ }^{184}$.

W województwie witebskim mandat otrzymali stronnik Czartoryskich oboźny litewski Leonard Pociej oraz podkomorzy witebski Józef Hurko, z kolei w powiecie orszańskim marszałek Mikołaj Sabba Chrapowicki oraz podczaszy orszański Paweł Bartoszewicz ${ }^{185}$.

Zgodnie z wolą Michała Czartoryskiego posłami z Brześcia zostali pisarz polny litewski Józef Sosnowski oraz łowczy nadworny litewski Józef Bystry. Na sejmiku zaś: „kasztelan brzeski [tj. Jan Antoni Horain] mocno [--] zelował na religię i prawami, aż na tym interesie in paritate limite zapisali"186. Ostatecznie w instrukcji brzeskiej widnieje antydysydencki

180 Bp J.D. Łopaciński do M. Łopacińskiego, 9 V, 6 X, 10 X 1766, LVIA, k. 135-136, 137-138, 231-232.

181 Z. Zielińska, Polska w okowach, s. 493.

182 M. Brzostowski do Stanisława Augusta, 26 VIII 1766, BC 656, s. 237-240; T. Burzyński do Stanisława Augusta, 1 IX 1766, BC 657; BC 656, s. 323-324; Deputaci Trybunału Głównego Wielkiego Księstwa Litewskiego (1697-1794). Spis, t. 2, red. A. Rachuba, P. Romaniuk, Warszawa 2004, s. 294; Urzędnicy, Litwa t. 2, s. 181, 556. Prawdopodobnie chodziło o Stanisława Jakuba Eydziatowicza, Urzędnicy, Litwa t. 4, s. 63.

183 L. Żytkowicz, Korsak Samuel, PSB, t. 14, s. 115.

184 W. Maciejewska, Chreptowicz Jan Litawor, PSB, t. 3, Warszawa 1937, s. 440-441; H. Waniczkówna, Dziekoński Antoni, PSB, t. 6, Kraków 1948, s. 131-132; Z. Zielińska, Oskierka Gerwazy Ludwik, PSB, t. 24, s. 358-360; W. Szczygielski, Z. Zielińska, Olędzki Stefan, PSB, t. 23, Warszawa 1978, s. 798-800.

185 Z. Zielińska, Pociej Leonard, PSB, t. 27, s. 37-38; T. Szwaciński, op. cit., s. 36; W. Konopczyński, Chrapowicki Mikołaj Sabba, PSB, t. 3, s. 439-440.

186 Bp J.D. Łopaciński do M. Łopacińskiego, 15 IX 1766, LVIA, k. 159-160. 
zapis. Z powiatu pińskiego posłami zostali sędzia ziemski piński Leopold Orzeszko oraz chorąży piński Korzeniecki.

Król opiekę nad sejmikiem mścisławskim oddał pisarzowi litewskiemu Mikołajowi Łopacińskiemu ${ }^{187}$. Czartoryscy zaś upatrywali w nim kandydata na posła. Owa funkcja nie była na rękę wyróżnionemu, który, choć sympatyzował z malkontentami, to obawiał się narazić dworowi ${ }^{188}$. Ostatecznie został posłem razem z protegowanym Familii chorążym Janem Suchodolskim.

Województwo mińskie reprezentowali pisarz ziemski Antoni Świętorzecki oraz łowczy Jan Pawlikowski, powiat mozyrski kasztelanic miński Marcin Teodor Oskierka i pisarz dekretowy Gedeon Jeleński, ziemię rzeczycką pisarz Kazimierz Chlewiński ze skarbnikiem Chełchowskim ${ }^{189}$.

Z województwa inflanckiego posłami zostali współpracujący z królem chorąży Jan Szadurski, podwojewodzic mścisławski Kazimierz Konstanty Plater, podkomorzy wiski Józef Wilczewski, chorąży czerwonogrodzki Kajetan Hryniewiecki, horodniczy brzeski Józef Dulęba oraz starosta czudziański Józef Kaszyc ${ }^{190}$.

Aby uzyskać pełny obraz kampanii sejmikowej 1766 r. konieczna jest analiza instrukcji. Ich treść oraz przydział mandatów wskazują na zdecydowaną przewagę dworu na sejmikach bełskim, grodzieńskim oraz kowieńskim. W instrukcjach ze wspomnianych ziem zgadzano się m.in. na przyznanie dysydentom nowych praw, oddanie czopowego i szelężnego, przemilczano sprawę rozwiązania konfederacji i chwalono króla za Szkołę Rycerską. Tamtejsza szlachta aprobowała także działalność komisji tudzież dziękowała za reformę monetarną.

Przebieg zgromadzeń i treść instrukcji pokazują, że w 1766 r. było więcej sejmików o bardziej malkontenckim niż prokrólewskim charakterze. I tak zdecydowanie opozycyjny ton miały instrukcje z Bielska, Dobrzynia, Drohiczyna, Liwu, Lublina, Łucka, Mścisławia, Pińska, Proszowic, Sandomierza, Sieradza, Środy, Wielunia, Włodzimierza, Wyszogrodu oraz Żytomierza. Wszystkie one były nastawione antydysydencko i żądały rozwiązania konfederacji generalnej wraz z tym, co „uciążliwego ustanowiła”. Jedne ogólnikowo krytykowały reformę

187 Stanisław August do M. Łopacińskiego, Biblioteka Wróblewskich, 22 VI 1766, F 119-16.

188 Bp J.D. Łopaciński do M. Łopacińskiego, 5 i 26 VII, 9 VIII 1766, LVIA, k. 127-128, 217, 223-224.

189 E. Rabowicz, Jeleński Gedeon, PSB, t. 11, Warszawa 1965, s. 140-141.

190 VL 7, s. 125; A. Haratym, Szadurski Jan, PSB, t. 46, s. 390-392; Z. Zielińska, Plater Kazimierz Konstanty, PSB, t. 26, Warszawa 1981, s. 665-672; E. Rostworowski, Hryniewicz Kajetan, PSB, t. 10, s. 60-61. 
monetarną ${ }^{191}$, inne zarzucały komisjom skarbowym bezprawną decyzję o redukcji monety ${ }^{192}$ tudzież nadużywanie kompetencji sądowniczych $^{193}$. Chcąc zmniejszyć wpływ króla na te urzędy, żądano, aby ich siedzibę przenieść poza stolicę ${ }^{194}$, a elekcji komisarzy dokonywać na sejmikach ${ }^{195}$. W celu dalszej decentralizacji władzy szlachta wielkopolska i czernihowska postulowały, żeby komisje przesyłały sprawozdania z działalności na sejmiki. Niemal wszystkie antykrólewskie instrukcje odmówiły reformy czopowego i szelężnego, jednocześnie domagając się likwidacji podymnego. Żądano ponadto opuszczenia kraju przez wojsko rosyjskie ${ }^{196}$, a także sprzeciwiano się zawieraniu przez Rzeczpospolitą traktatów z innymi państwami, tzn. z Rosją ${ }^{197}$.

Warto zauważyć, że w instrukcjach o zdecydowanie opozycyjnym tonie pojawiały się także mniej popularne postulaty jak przywrócenie hetmanom pełni władzy ${ }^{198}$ czy likwidacja komisji wielkich ${ }^{199}$. Niewielkie poparcie dla powyższych żądań można uznać za sukces dworu. W instrukcjach pojawiły się też punkty optujące za zwrotem zasekwestrowanych w 1764 r. dóbr jednego z czołowych opozycjonistów - Karola Stanisława Radziwiłła „Panie Kochanku”200, umocnieniem wolnej elekcji ${ }^{201}$, zwiększeniem liczby komisarzy pracujących nad rozgraniczeniem z Rosją ${ }^{202}$ czy ograniczeniem wydatków na remont Zamku Królewskiego w Warszawie $^{203}$. Niektóre sejmiki zastrzegły, aby przy kodyfikacji nie próbowano wprowadzać nowego prawa ${ }^{204}$. Pojawił się ponadto pomysł wysłania komisji do Kurlandii w celu zbadania losu tamtejszych katolików ${ }^{205}$.

191 Bracławska, mścisławska, pińska, proszowicka, sieradzka, wiłkomierska, wyszogrodzka.

192 Bielska, bracławska, czernihowska, drohicka, liwska, łucka, proszowicka, ruska, sandomierska, starodubowska, wieluńska.

193 Łęczycka, mścisławska, proszowicka, sandomierska, sieradzka, wielkopolska, wieluńska, wiłkomierska, wiska.

${ }^{194}$ Czernihowska, lubelska, łucka, sieradzka.

195 Bracławska, dobrzyńska, drohicka, liwska, lubelska, łucka, sieradzka (ta proponowała na sejmikach gospodarskich), ruska, wieluńska, wyszogrodzka.

196 Bielska, brzeska, drohicka, lubelska, mścisławska, pińska, proszowicka, sieradzka, starodubowska.

197 Bracławska, drohicka, łucka, nurska, proszowicka, starodubowska.

198 Bielska, czernihowska, dobrzyńska, sieradzka, wieluńska.

199 Mścisławska.

200 Bielska.

201 Mścisławska.

202 Pińska, sieradzka, starodubowska, wiłkomierska.

203 Bielska, proszowicka.

204 Bracławska, lubelska, łucka, mścisławska oraz sieradzka.

${ }^{205}$ Krakowska, lubelska. 
Proponowano również, żeby kosztami związanymi z aukcją obciążyć duchowieństwo oraz króla ${ }^{206}$. Szlachta pruska z kolei domagała się utrzymania swojej autonomii ${ }^{207}$.

Jednak wielu sejmików nie da się jednoznacznie określić jako prokrólewskie lub malkontenckie. Najwyraźniej do stworzenia instrukcji oraz wyboru posłów mogło tam dojść w wyniku porozumienia między zwolennikami i przeciwnikami króla. I tak spośród dziesięciu sejmików, które uchwaliły punkt w sprawie innowierców zgodnie z wolą króla ${ }^{208}$, w trzech instrukcjach: łęczyckiej, warszawskiej oraz starodubowskiej pojawiły się wyraźne zastrzeżenia pod adresem komisji skarbowych, z kolei szlachta halicka domagała się rozwiązania konfederacji generalnej, łęczycka zaś żądała pozostawienia czopowego i szelężnego w gestii ziem i powiatów. W instrukcji starodubowskiej, zawierającej prokrólewskie postulaty, pojawił się atak na reformę monetarną. Instrukcja brzeska, choć odmówiła praw dysydentom, to chwaliła działalność komisji skarbowych. Zwolennikom króla niekiedy udało się coś przemycić także do instrukcji wyraźnie opozycyjnych. I tak żądanie szlachty pińskiej dotyczące rozwiązania konfederacji obwarowano propozycją, aby jej dotychczasowe uchwały pozostały w mocy, mścisławska zaś i bielska godziły się na zmianę czopowego i szelężnego, a w Żytomierzu decyzję o trwaniu konfederacji generalnej pozostawiono w gestii sejmu.

Aprobatę ponad podziałami politycznymi zyskała Szkoła Rycerska, co wyrażono w 22 instrukcjach ${ }^{209}$, choć kosztami jej utrzymania planowano obciążyć króla i duchowieństwo ${ }^{210}$. Kolejną sprawą łączącą szlachtę o odmiennych afiliacjach politycznych był stosunek do dysydentów. W 25 instrukcjach sprzeciwiono się zmianom na ich korzyść ${ }^{211}$. Poza tym

${ }^{206}$ Dobrzyńska, mścisławska, pińska.

207 O wynikach generału pruskiego J. Dygdała, Życie polityczne, s. 183-184.

208 Bełski, grodzieński, halicki, kowieński, łęczycki, starodubowski, upicki, warszawski, wiłkomierski i żmudzki. Nie dotarłam do instrukcji żmudzkiej i upickiej. O zawartym w nich punkcie prodysydenckim Z. Zielińska, Polska w okowach, s. 493.

${ }^{209}$ Bełska, bracławska, brzeska, ciechanowska, generału pruskiego, grodzieńska, halicka, kijowska, kowieńska, liwska, lubelska, łęczycka, łomżyńska, łucka, pińska, sandomierska, sochaczewska, starodubowska, warszawska, wiłkomierska, wiska, zakroczymska.

${ }^{210}$ Ciechanowska, liwska, sandomierska, sochaczewska, warszawska, wiłkomierskia, wiska.

211 Bielska, bracławska, brzeska, ciechanowska, czernihowska, dobrzyńska, drohicka, generału pruskiego, halicka, kijowska, lubelska, łomżyńska, łucka, mścisławska, nurska, pińska, płocka, proszowicka, ruska, sandomierska, sieradzka, sochaczewska, wielkopolska, wieluńska, zakroczymska. 
w ponad połowie ze znanych dokumentów żądano także rozwiązania konfederacji generalnej ${ }^{212}$ oraz likwidacji podymnego wraz z pogłównym $^{213}$. W 14 instrukcjach odmówiono reformy czopowego i szelężnego ${ }^{214}$. Odnośnie do problemu kurlandzkiego 15 sejmików uznało konieczność znalezienia konsensu między księciem a szlachtą, ale bez uszczerbku dla tej ostatniejej.

Moje badania potwierdzają obserwację zawartą w relacjach źródłowych, że zwolennicy Stanisława Augusta tam, gdzie znaleźli się w defensywie, porzucali walkę o instrukcje i koncentrowali swoje wysiłki na obsadzeniu mandatów, licząc, że na sejmie wszystko będzie zależało od decyzji posłów. Stąd, choć instrukcje bielska, dobrzyńska, krakowska, lidzka, mścisławska, sieradzka i sochaczewska miały mniej lub bardziej opozycyjny charakter, to jednak zdecydowana większość posłów z tych ziem była prokrólewska. Do konsensu przy podziale mandatów doszło w przypadku Wielkopolski, Wołynia, sejmików bełskiego, drohickiego i podolskiego. Z powyższego wynika, iż słuszna była obserwacja Repnina, że król większość sejmików obsadził swoimi zwolennikami ${ }^{216}$.

Opozycja dobrze przygotowała się do sejmików poselskich 1766 r., a do ataku na dwór posłużyła sprawa dysydencka. Po żądaniu utrzymania pozycji religii katolickiej utożsamianej z wolnościami szlacheckimi pojawiały się postulaty wymierzone w reformy. Opozycja wykorzystała ponadto niezadowolenie szlachty z powodu redukcji monety oraz chęć przejęcia przez króla dochodów z czopowego i szelężnego. W Prusach Królewskich zaś narzędziem do antagonizowania szlachty była walka o utrzymanie przywilejów prowincji, a na ziemiach wschodnich żądanie wyjścia wojsk rosyjskich oraz szerzenie pogłosek o projektowanym przez dwór zniesieniu pańszczyzny. Wszystko to potwierdza obserwację

212 Bielska, brzeska, dobrzyńska, drohicka, halicka, liwska, lubelska, łęczycka, łomżyńska, mścisławska, pińska, płocka, proszowicka, sandomierska, sieradzka, wielkopolska, wieluńska, wiłkomierska, wyszogrodzka.

213 Brzeska, ciechanowska, generału pruskiego, grodzieńska, liwska, lubelska, mścisławska, pińska, ruska, sandomierska, sieradzka, warszawska, wielkopolska, wieluńska, wiłkomierska, wiska, wyszogrodzka, zakroczymska. Dobrzyńska i proszowicka nie wyraziły tego życzenia wprost, a jedynie sformułowaniem, żeby zlikwidować podatki obciążające szlachtę.

${ }^{214}$ Drohicka, generału pruskiego, lubelska, łęczycka, nurska, proszowicka, ruska, sochaczewska, wielkopolska, wyszogrodzka; liwska, sandomierska oraz wieluńska jako warunek stawiały likwidację pogłównego, pińska zaś proponowała, aby na żołd żołnierzom wydzielić z litewskiego czopowego jakąś kwotę.

${ }^{215}$ Bracławski, brzeski, ciechanowski, kijowski, kowieński, łęczycki, łucki, mścisławski, nurski, płocki, sandomierski, starodubowski, wielkopolski, wieluński, wiski.

${ }^{216}$ Z. Zielińska, Polska w okowach, s. 494. 
Jerzego Michalskiego, że przed 1767 r. opozycja potrzebowała parawanu ochronnego dla akcji antykrólewskiej ${ }^{217}$.

Wyraźnie też widać, że w kampanii sejmikowej obóz rządzący nie współpracował ze sobą w pełni ani na płaszczyźnie programu politycznego, ani polityki personalnej. Czartoryscy nie przeciwdziałali umieszczaniu w instrukcjach treści antydysydenckich i broniących wolności szlacheckich. Starali się także zachować kontrolę nad obsadą mandatów. Tymczasem Stanisław August nie dysponował własnym stronnictwem i musiał iść na ustępstwa wobec wpływowych wujów. Podejmował jednak próby emancypacji. Udało mu się uzyskać przewagę na kilku sejmikach: w Bełzie za sprawą brata Kazimierza, w Grodnie Antoniego Tyzenhauza, w Haliczu Tadeusza Dzieduszyckiego, w Kownie Zabiełłów, a w Warszawie zapewne Stanisława Sobolewskiego. Opozycja dostrzegła brak jedności na dworze i obserwowała go z nieufnością, choć działał na jej korzyśćc ${ }^{218}$. Plotki o „konflikcie na górze” utrudniły staroście Raczyńskiemu robotę sejmikową w Wielkopolsce, podsycały opór Katarzyny Kossakowskiej w sporze z Dzieduszyckim, a także były przyczyną snucia różnych domysłów na temat rzeczywistych relacji na dworze warszawskim w województwie mścisławskim ${ }^{219}$.

Kampania sejmikowa 1766 r. była ciężką batalią dla króla. Pozbawiony należytego wsparcia ze strony Familii, został zmuszony do forsowania niepopularnych wśród szlachty postulatów prodysydenckich, a jednocześnie musiał się zmierzyć z dobrze zorganizowaną opozycją.

\section{Streszczenie}

Niniejszy artykuł traktuje o sejmikach poselskich z 1766 r. i składa się z dwóch części. Pierwsza stanowi analizę przygotowań króla do sejmików, czyli omawia jego program polityczny, relacje z Rosją oraz współpracę z Czartoryskimi. Następnie autorka bada, jakie postulaty wysunęła opozycja na nadchodzący sejm oraz jakie kroki przedsięwzięła, aby osiągnąć własne cele na sejmikach.

Druga część z kolei to analiza przebiegu poszczególnych zgromadzeń, a także instrukcji, w które zaopatrzono posłów. Dla niektórych sejmików brakowało materiałów źródłowych, dlatego wiadomo jedynie, komu przydzielono tam mandat, w przypadku innych istnieje korespondencja umożliwiająca odtworzenie przebiegu zgromadzeń oraz ustalenie posłów obranych po myśli króla tudzież opozycji.

217 J. Michalski, Propaganda, s. 536-539; idem, Warszawa, s. 38-42.

218 M. Wielhorski do J. Mniszcha, 9 III 1766, BC 3861, s. 171-177.

${ }^{219}$ J.D. Łopaciński do M. Łopacińskiego, 22 IX 1766, LVIA, k. 161-162. 
W podsumowaniu próbowano odpowiedzieć na pytanie, czemu postulaty malkontentów znalazły posłuch wśród szlachty, jakie okoliczności utrudniały skuteczne działanie króla w kampanii, a także czyim sukcesem okazały się sejmiki 1766 r.

\section{The Dietines of 1766}

The article deals with the dietines (sejmiki, assemblies of the local nobility) of 1766 , and is divided into two parts. The first part is an analysis of the preparations made by the king for the dietines, that is, it describes his political programme, relations with Russia, and cooperation with the Czartoryski family. Next, the author examines the demands put forward by the opposition to the upcoming Sejm (Parliament, Diet), and the steps they had taken at the dietines to promote their own interests. The second part, in turn, is an analysis of the course of individual assemblies together with the instructions of the envoys. For some of the dietines, source material is not extant, and we only know who obtained a mandate; for others, there is a correspondence making it possible to reconstruct the course of the sessions and establish the names of the envoys elected according to the wish either of the king, or the opposition. In the conclusion, an attempt is made to answer the questions of why the demands of the malcontents gained the ear of the nobility, what were the circumstances that hampered the king's actions during this campaign, and who, in fact, was victorious at the 1766 dietines.

Translated by Grażyna Waluga

\section{Bibiliografia}

Achremczyk Stanisław, Życie sejmikowe Prus Królewskich w latach 1647-1772, Ośrodek Badań Naukowych im. W. Kętrzyńskiego, Olsztyn 1999.

Bednaruk Waldemar, Sejmiki lubelskie w okresie stanisławowskim (1764-1794), Wydawnictwo KUL, Lublin 2011.

Borkowska-Bagieńska Ewa, „Zbiór praw sądowych” Andrzeja Zamoyskiego, UAM, Poznań 1986.

Chojecki Ryszard, Markowski Józef, PSB, t. 20, Warszawa 1975, s. 43-44.

Czeppe Maria, Kamaryla Pana z Dukli. Kształtowanie się obozu politycznego Jerzego Augusta Mniszcha, 1750-1763, Neriton, IH PAN, Warszawa 1998.

Deputaci Trybunału Głównego Wielkiego Księstwa Litewskiego (1697-1794). Spis, t. 2, red. Andrzej Rachuba, Przemysław P. Romaniuk, DiG, Warszawa 2004.

Dolinskas Vydas, Simonas Kosakovskis. Politiné ir kariné veikla Lietuvos Didžiojoje Kunigaikštystèje. 1763-1794, Vaga, Vilnius 2003.

Dolinskas Vydas, Szymon Kossakowski. Dzieje jednej kariery. Znane i nieznane fakty z biografii, „Krakowskie Pismo Kresowe” 3, 2011, s. 79-101.

Dukwicz Dorota, Sobolewski Stanisław z Piętek, PSB, t. 39, Kraków 1999-2000, s. 590591. 
Dukwicz Dorota, Zwierzykowski Michał, Sułkowski August, PSB, t. 45, Warszawa 2007-2008, s. 542-553.

Dumanowski Jarosław, Sumiński Piotr, PSB, t. 45, Warszawa 2007-2008, s. 603-607. Dygdała Jerzy, Przebendowski Ignacy Franciszek, PSB, t. 28, Kraków 1984-1985, s. 644647.

Dygdała Jerzy, Przyłubski Wacław, PSB, t. 29, Warszawa 1986, s. 204.

Dygdała Jerzy, Raczyński Kazimierz, PSB, t. 29, Kraków 1986, s. 644-653.

Dygdała Jerzy, Życie polityczne Prus Królewskich u schyłku ich związku z Rzecząpospolita w XVIII wieku. Tendencje unifikacyjne a partykularyzm, PWN, Warszawa 1984.

Dymnicka Hanna, Łętowski Stanisław h. Ogończyk (zm. 1776), PSB, t. 18, Kraków 1973, s. 365-367.

Dymnicka-Wołoszyńska Hanna, Ossoliński Aleksander, PSB, t. 24, Wrocław 1979, s. $388-390$.

Głowacki Jerzy Józef, Gastronomia polityczna kuchmistrza litewskiego. Michał Wielhorski (ok. 1731-1814) - życie i myśl ustrojowa, DiG, Warszawa 2014.

Goliński Zbigniew, Krasicki Ignacy Błażej Franciszek, PSB, t. 15, Kraków 1970, s. 144150.

Haratym Andrzej, Szadurski Jan, PSB, t. 46, Warszawa 2010, s. 390-392.

Haratym Andrzej, Szaniawski Adam, PSB, t. 46, Kraków 2010, s. 613-615.

Jurgaitis Robertas, „Vilniaus seimelio veikla 1717-1795 m.” (mps doktoratu).

Jurgaitis Robertas, Funkcjonowanie sejmiku wileńskiego w latach 1717-1795. Między szlacheckim parlamentaryzmem a samorzadem, w: Praktyka życia publicznego w Rzeczypospolitej Obojga Narodów w XVI-XVIII wieku, red. Urszula Augustyniak, Andrzej B. Zakrzewski, IH PAN, Neriton, Warszawa 2010, s. 35-53.

Jusupović Monika, Prowincjonalna elita litewska w XVIII wieku. Działalność polityczna rodziny Zabiełtów w latach 1733-1795, PTH, IH PAN, Neriton, Warszawa 2014.

Kizwalter Tomasz, Ostrowski Tomasz Adam, PSB, t. 24, Wrocław 1979, s. 579-583.

Kobierecki Michał, Walewscy herbu kolumna w XVII-XVIII wieku. Genealogia, majętność, działalność polityczna, Ibidem, Łódź 2008.

Kociszewski Aleksander, Mikorski Józef Andrzej, PSB, t. 21, Warszawa 1976, s. 163-164.

Konopczyński Władysław, Chrapowicki Mikołaj Sabba, PSB, t. 3, Kraków 1937, s. 439440.

Konopczyński Władysław, Dąmbski Jan Chrzciel z Lubrańca, PSB, t. 5, Kraków 19391946, s. 33.

Konopczyński Władysław, Gadomski Stanisław Kostka, PSB, t. 7, Kraków 1958, s. 200-202.

Konopczyński Władysław, Kossakowski Szymon Marcin, PSB, t. 14, Wrocław 19681969, s. 288-293.

Kosińska Rozalia, Wpływ opozycji na przebieg i wyniki sejmiku poselskiego w Proszowicach w 1766 roku, w: Zmierzch i świt. Stanisław August i Rzeczpospolita 1764-1795, red. Aleksandra Antoniewicz, Rozalia Kosińska, Piotr Skowroński, Neriton, Warszawa 2015, s. 65-82.

Kościałkowski Stanisław, Antoni Tyzenhauz. Podskarbi nadworny litewski, t. 1, Wydaw. Społeczności Akademickiej Uniwersytetu Stefana Batorego, Londyn 1970.

Kozyrski Robert, Duchowieństwo, kościoły i religia w dokumentach sejmików województwa ruskiego w epoce konfesjonalizacji Rzeczypospolitej Obojga Narodów 1648-1768, Towarzystwo Naukowe KUL, Lublin 2013. 
Krakowski Bernard, Kossowski Antoni, PSB, t. 14, Wrocław 1968-1969, s. 309-311.

Krakowski Bernard, Kossowski Roch, h. Dołęga, PSB, t. 14, Wrocław 1968-1969, s. $317-$ 319.

Krakowski Bernard, Kossowski Stanisław, PSB, t. 14, Wrocław 1968-1969, s. 320.

Kriegseisen Wojciech, Dysydenci i dyzunici w Rzeczypospolitej epoki stanisławowskiej, w: Stanisław August i jego Rzeczpospolita. Dramat państwa, odrodzenie narodu, t. 2, red. Angela Sołtys, Zofia Zielińska, Arx Regia. Ośrodek Wydawniczy Zamku Królewskiego, Warszawa 2013, s. 51-63.

Kriegseisen Wojciech, Sejmiki Rzeczypospolitej szlacheckiej w XVII i XVIII wieku, Wydawnictwo Sejmowe, Warszawa 1991.

Kuras Katarzyna, Wspótpracownicy i klienci Augusta A. Czartoryskiego w czasach saskich, Historia Iagellonica, Kraków 2010.

Kurdybacha Łukasz, Dzieje Kodeksu Andrzeja Zamoyskiego, Czytelnik, Kraków 1951.

Łubieńska Maria Cecylia, Sprawa dysydencka 1764-1766, Gebethner i Wolff, Warszawa 1911.

Łukowski Jerzy, The Papacy, Poland, Russia and religious reform 1764-8, „Journal of Ecclesiastical History" 39, 1988, s. 66-94.

Łukowski Jerzy, The szlachta and the Confederacy of Radom 1764-1767/1768. A Study of the Polish Nobility, Institutum Historicorum Polonicum Romae, Rzym 1977.

Maciejewska Wanda, Chreptowicz Jan Litawor, PSB, t. 3, Warszawa 1937, s. 440-441. Michalski Jerzy, Jabłonowski Roch Michał, PSB, t. 10, Kraków 1962, s. 231-232.

Michalski Jerzy, Karczewski Józef, PSB, t. 12, Warszawa 1967, s. 32-33.

Michalski Jerzy, Problematyka aliansu polsko-rosyjskiego w: Jerzy Michalski, Studia historyczne z XVIII i XIX wieku, t. 1: Polityka i społeczeństwo, Stentor, Warszawa 2007, s. 335-362.

Michalski Jerzy, Propaganda konserwatywna $w$ walce z reforma w poczatkach panowania Stanisława Augusta, PH 43, 1952, 3-4, s. 536-562.

Michalski Jerzy, Warszawa, czyli o antyspołecznych nastrojach $w$ czasach Stanisława Augusta, w: Jerzy Michalski, Studia historyczne z XVIII i XIX wieku, t. 2: Ideologia, nauka, historiografia, Stentor, Warszawa 2007, s. 37-96.

Michalski Jerzy, Zagadnienie reformy sądownictwa i prawa sądowego w początkach panowania Stanisława Augusta, CPH 52, 2000, 1-2, s. 67-109.

Nieć Julian, Czetwertyński-Światopełk Aleksander, PSB, t. 4, Kraków 1938, s. 357-358.

Nycz Michał, Geneza reform skarbowych Sejmu Niemego. Studium z dziejów skarbowo-wojskowych z lat 1697-1717, PTPN, Poznań 1938.

Orman Elżbieta, Sanguszko Hieronim, PSB, t. 34, Kraków 1992-1993, s. 484-488.

Przyboś Kazimierz, Sejmik województwa krakowskiego w czasach saskich (1697-1763), Uniwersytet Jagielloński, Kraków 1981.

Rabowicz Edmund, Jeleński Gedeon, PSB, t. 11, Warszawa 1965, s. 140-141.

Rostworowski Emanuel, Hryniewicz Kajetan, PSB, t. 10, Warszawa 1964, s. 60-61.

Rostworowski Emanuel, Sprawa aukcji wojska na tle sytuacji politycznej przed sejmem czteroletnim, PWN, Warszawa 1957.

Rudnicki Kazimierz, Biskup Kajetan Sołtyk 1715-1788, Gebethner i Wolff, Warszawa 1906.

Serczyk Władysław A., Wereszycka Helena, Lubomirski Kasper, PSB, t. 18, Kraków 1973, s. 28-30. 
Szczygielski Wacław, Kuczyński Leon Michał, PSB, t. 16, Warszawa 1971, s. 88-89. Szczygielski Wacław, Lasocki Antoni, PSB, t. 16, Warszawa 1971, s. 537.

Szczygielski Wacław, Łoś Feliks, PSB, t. 18, Warszawa 1973, s. 429-431.

Szczygielski Wacław, Mączyński Jan Antoni, PSB, t. 20, Kraków 1975, s. 339-341.

Szczygielski Wacław, Mieczyński Władysław, PSB, t. 20, Warszawa 1975, s. 738-739.

Szczygielski Wacław, Morzkowski Antoni, PSB, t. 22, Warszawa 1977, s. 25-28.

Szczygielski Wacław, Nakwaski Cyprian, PSB, t. 22, Warszawa 1977, s. 478-479.

Szczygielski Wacław, Ostrowski Wojciech, PSB, t. 24, Wrocław 1979, s. 591-592.

Szczygielski Wacław, Podhorodeński Józef, PSB, t. 27, Kraków 1983, s. 98-99.

Szczygielski Wacław, Potocki Teodor, PSB, t. 28, Warszawa 1984, s. 213-216.

Szczygielski Wacław, Przyłuski Tadeusz, PSB, t. 29, Warszawa 1986, s. 212-214.

Szczygielski Wacław, Wojciechowski Bronisław, Przyjemski Ignacy, PSB, t. 29, Warszawa 1986, s. 175-178.

Szczygielski Wacław, Zielińska Zofia, Olędzki Stefan, PSB, t. 23, Warszawa 1978,

s. $798-800$.

Szwaciński Tomasz, Sejmiki poselskie przed konwokacją 1764 r., KH 113, 2006, 1, s. 19-56. Urzędnicy

t. 1, z. 2 - Urzędnicy wielkopolscy XVI-XVIII wieku. Spisy, oprac. Adam Bieniaszewski, Ossolineum, Wrocław 1987.

t. 2, z. 2 - Urzędnicy województw łęczyckiego i sieradzkiego XVI-XVIII wieku. Spisy, oprac. Edward Opaliński, Hanka Żerek-Kleszcz, Biblioteka Kórnicka, Kórnik 1993.

t. 3, z. 1 - Urzędnicy województwa ruskiego XIV-XVIII wieku (ziemie halicka, lwowska, przemyska, sanocka). Spisy, oprac. Kazimierz Przyboś, Ossolineum, Wrocław 1987.

t. 3, z. 2-Urzędnicy województwa bełskiego i ziemi chełmskiej XIV-XVIII wieku. Spisy, oprac. Henryk Gmiterek, Ryszard Szczygieł, Biblioteka Kórnicka, Kórnik 1992.

t. 3, z. 4 - Urzędnicy województw kijowskiego i czernihowskiego XV-XVIII wiek. Spisy, oprac. Eugeniusz Janas, Witold Kłaczewski, Biblioteka Kórnicka, Kórnik 2002.

t. 4, z. 2 - Urzędnicy województwa krakowskiego XVI-XVIII wieku. Spisy, oprac. Stanisław Cynarski, Alicja Falniowska-Gradowska, Biblioteka Kórnicka, Kórnik 1990.

t. 4, z. 3 - Urzędnicy województwa sandomierskiego XVI-XVIII wiek. Spisy, oprac. Krzysztof Chłapowski, Alicja Falniowska-Grabowska, Biblioteka Kórnicka, Kórnik 1993.

t. 4, z. 4 - Urzędnicy województwa lubelskiego XVI-XVIII wieku. Spisy, oprac. Witold Kłaczewski, Wacław Urban, Biblioteka Kórnicka, Kórnik 1991.

t. 6, z. 2 - Urzędnicy kujawscy i dobrzyńscy XVI-XVIII wieku. Spisy, oprac. Krzysztof Mikulski, Wojciech Stanek, Biblioteka Kórnicka, Kórnik 1990.

t. 8 - Urzędnicy podlascy XIV-XVIII wieku. Spisy, oprac. Ewa Dubas-Urwanowicz, Biblioteka Kórnicka, Kórnik 1994.

t. 10 - Urzędnicy centralni i nadworni Polski XIV-XVIII wieku. Spisy, oprac. Krzysztof Chłapowski, Stefan Ciara, Biblioteka Kórnicka, Kórnik 1992.

Urzędnicy, Litwa

t. 1 - Województwo wileńskie XIV-XVIII wiek, red. Andrzej Rachuba, oprac. Henryk Lulewicz, Andrzej Rachuba, Przemysław P. Romaniuk, współpraca Uładzimir Jemialianczuk, Andrej Macuk, DiG, Warszawa 2004. 
t. 2 - Województwo trockie XIV-XVIII wiek, red. Andrzej Rachuba, oprac. Henryk Lulewicz, Andrzej Rachuba, Przemysław P. Romaniuk, Andrzej Haratym, współpraca Andrej Macuk, Jaugien Aniszczanko, DiG, Warszawa 2009.

t. 4 - Ziemia smoleńska i województwo smoleńskie XIV-XVIII wiek, red. Andrzej Rachuba, oprac. Henryk Lulewicz, Andrzej Rachuba, Przemysław P. Romaniuk, DiG, Warszawa 2003.

Waniczkówna Helena, Boreyko Pius Franciszek, PSB, t. 2, Kraków 1936, s. 325. Waniczkówna Helena, Dziekoński Antoni, PSB, t. 6, Kraków 1948, s. 131-132. Zahorski Andrzej, Małachowski Stanisław, PSB, t. 19, Kraków 1974, s. 415-420. Zakrzewski Andrzej B., Sejmiki Wielkiego Księstwa Litewskiego XVI-XVIII w. - ustrój i funkcjonowanie. Sejmik trocki, Liber, Warszawa 2000.

Zielińska Zofia, Małachowski Adam, PSB, t. 19, Kraków 1974, s. 386-388.

Zielińska Zofia, Mogilnicki Józef Teodor, PSB, t. 21, Kraków 1976, s. 562-563.

Zielińska Zofia, Oskierka Gerwazy Ludwik, PSB, t. 24, Wrocław 1979, s. 358-360.

Zielińska Zofia, Ożarowski Piotr, PSB, t. 24, Wrocław 1979, s. 673-679.

Zielińska Zofia, Plater Kazimierz Konstanty, PSB, t. 26, Warszawa 1981, s. 665-672.

Zielińska Zofia, Pociej Leonard, PSB, t. 27, Warszawa 1983, s. 37-38.

Zielińska Zofia, Polska w okowach „systemu północnego” 1763-1766, Arcana, Kraków 2012.

Zielińska Zofia, Rzeczpospolita między Prusami a Rosją w świetle polsko-pruskiego sporu o cto generalne, KH 115, 2008, 2, s. 5-52.

Zielińska Zofia, Rzewuski Józef, PSB, t. 34, Warszawa 1993, s. 112-113.

Zielińska Zofia, Sapieha Aleksander, PSB, t. 34, Kraków 1992-1993, s. 565-569.

Zielińska Zofia, Szymanowski Michat, PSB, t. 50, Warszawa 2014, s. 98-99.

Złomska Małgorzata, Oskierka Antoni Joachim, PSB, t. 24, Wrocław 1979, s. 357-358.

Zwierzykowski Michał, Akta sejmikowe województw poznańskiego i kaliskiego. Lata 1733-1763, DiG, Warszawa 2015.

Zwierzykowski Michał, Komisja skarbowa poznańska. Z dziejów sejmikowej administracji i sadownictwa skarbowego w Wielkopolsce w XVII i XVIII wieku, Wydawnictwo Poznańskie, Poznań 2003.

Zwierzykowski Michał, Samorząd sejmikowy województw poznańskiego i kaliskiego w latach 1696-1732, Wydawnictwo Poznańskie, Poznań 2010.

Zwierzykowski Michał, Tacka Ewa, Miejsca obrad sejmików województwa Wielkopolski właściwej od XVI do XVIII wieku, „Res Historica” 42, 2006, s. 75-100.

Żytkowicz Leonid, Korsak Samuel, PSB, t. 14, Warszawa 1969, s. 115.

Носов Борис, Установление российского господства в Речи Посполитой. 1756-1768 г2., Индрик, Москва 2004.

Biogram: doktorantka w Instytucie Historii PAN; pracę doktorską na temat konfederacji radomskiej pisze pod kierunkiem prof. dr hab. Wojciecha Kriegseisena; obszar zainteresowań badawczych: okres panowania Stanisława Augusta; kontakt: rozaliakosinska@onet.pl. 